\title{
Wind Structure of a Subtropical Squall Line in China: Results from Dual-Doppler Radar Data
}

\author{
Haiguang Zhou \\ State Key Laboratory of Severe Weather, Chinese Academy of Meteorological Science, No. 46 Zhongguancun Nandajie, \\ Haidian District, Beijing 100081, China
}

Correspondence should be addressed to Haiguang Zhou; zhg@camscma.cn

Received 4 May 2016; Revised 18 August 2016; Accepted 30 August 2016

Academic Editor: Mario M. Miglietta

Copyright (c) 2016 Haiguang Zhou. This is an open access article distributed under the Creative Commons Attribution License, which permits unrestricted use, distribution, and reproduction in any medium, provided the original work is properly cited.

A subtropical squall line moved from Guangxi to Guangdong province in South China on 23-24 April 2007, which resulted in gale and heavy precipitation. The three-dimensional (3D) wind field of the squall line in its mature period was retrieved by GuangzhouShenzhen dual-Doppler data. The 3D conceptual model of this squall line was proposed. On the horizontal plane, the storm-relative front-to-rear inflow prevailed at the lower altitudes of the leading edge. The rear-to-front cold inflow in the stratiform region was observed below $3 \mathrm{~km}$ height, which enhanced the convergence in the convective region. At the middle altitudes of the squall line, the front-to-rear horizontal flow prevailed. Strong updrafts were observed at the lower and middle altitudes of the leading edge. Some convergence centers were located at the lower altitudes of the convective region. Furthermore, the storm-relative flow in the vertical cross-section perpendicular to the squall line was revealed. The front-to-rear warm flow extended from the surface to $7.5 \mathrm{~km}$ altitude at the leading edge. Above it, part of the front-to-rear inflow blew upward and then forward, and the other part of the inflow blew backward. The descending rear-to-front cold flow was only seen below $3 \mathrm{~km}$ height in the stratiform region.

\section{Introduction}

A squall line is severe weather which can produce gale, thunderstorm, hailstone, and heavy precipitation [1-6]. The stages of a squall line include initiation, development, mature, and dissipation stage [7]. The mature squall line contains an upshear-tilted, multicellular convective region with heavy precipitation and active updraft cell generation along the gust front, a transition zone of lighter precipitation, and a low-level radar reflectivity minimum between the convective and stratiform regions, followed by a region of moderate rainfall in the trailing stratiform region [2, 7-10]. Many researches have focused on its mechanism and structure [10$22]$. Because weather radar can supply high temporal and spatial observation data, it is an important tool to study the precipitation system and forecast the weather [17, 19, 23-32]. Dual-Doppler radar wind retrieval algorithm can give precise wind field. It has played an important role in revealing the fine kinematic structure of severe weather since the 1970s [33-37], especially the kinematic structure of a squall line.

Squall lines often form in the tropical area. The tropical squall line structure has been investigated by dual-radar retrieval wind [2, 3, 10, 13-15, 38]. Chong et al. [3] have found that the front-to-rear flow is located at the leading edge, and the rear-to-front flow is located in a layer of $3 \mathrm{~km}$ thick in the stratiform region. The mesoscale downdraft in the reflectivity trough [3] (i.e., transition zone) is located in a deep layer from the surface to approximately $6 \mathrm{~km}$, while the downdraft in the stratiform region occurs below the anvil-base altitudes (0$4 \mathrm{~km})$.

The structural characteristics of the midlatitude squall line have been reported in many studies [4, 12, 18, 22, 39-42]. Kessinger et al. [4] have pointed out the differences between a tropical squall line and a midlatitude squall line. The latter showed intense convective cloud along the leading edge, a less-pronounced bright band, and a reversal in the direction of storm-relative flow at the upper altitudes ahead of the squall line. Bright band is a distinct characteristic observed by a weather radar that denotes the freezing level of the atmosphere. The freezing level in a cloud contains ice particles that are coated with liquid water. These particles reflect significantly more radiation than the portions of the cloud above and below the freezing layer. Those characteristics of 
the bright bands in tropical, subtropical, and midlatitude squall lines are consistent. Houze et al. [9] have proposed the conceptual model of a midlatitude squall line following a dual-Doppler analysis. The storm-relative front-to-rear inflow is observed from the lower to the upper altitudes, and the storm-relative subsiding rear inflow is found at the lower and middle altitudes.

Dual-Doppler radar retrieval data have been applied to investigate the kinematic structure of subtropical squall lines in the Taiwan Strait in Taiwan Area Mesoscale Experiment (TAMEX) [43-46] and a squall-line-like tropical cyclone rainband [47]. Wang et al. [43] have pointed out that the front-to-rear flow prevails at all altitudes at the front of the squall line. The rear-to-front flow prevailing at the rear of the squall line is shallow compared with that of the midlatitude squall line [9]. However, the average updraft is slightly stronger than that of a tropical squall line.

By contrast, the study on the three-dimensional (3D) fine structure of the squall line on Mainland China is insufficient. In the past decade, the China Meteorology Administrator (CMA) has set up more than 170 China New Generation Doppler Weather Radars (CINRAD). The CINRAD include S-band and C-band Doppler weather radar. In some areas, some dual-Doppler weather radar networks have been established. On 24 April 2007, a subtropical squall line affected Guangdong province in South China. It caused gale, thunderstorm, and heavy precipitation. In its mature stage, the squall line passed through Guangzhou-Shenzhen dual-Doppler observation domain. It is a good opportunity to study the $3 \mathrm{D}$ kinematic structure of this subtropical squall line. What were the structural characteristics of this squall line? What were the new structures compared with the previously studied squall lines in the tropical, subtropical, and midlatitude areas?

This paper focuses on these questions. We begin by describing the data and the dual-Doppler wind retrieval method in Section 2. In Section 3, we first investigate the environment characteristics associated with the squall line and analyse the mesoscale system evolution using the reflectivity mosaic data and the mesonet data simultaneously. Then, we study the horizontal and vertical structural features of the squall line in its mature period using dual-Doppler retrieval wind. Section 4 discusses its characteristics compared with those of other squall lines in the subtropical areas. The $3 \mathrm{D}$ conceptual model of the squall line is summarized in Section 5 .

\section{Data and Method}

The dual-Doppler radar network includes CINRAD/SA (Sband, A-type) Doppler radars in Guangzhou and Shenzhen, which is in the central of Pearl River Delta of China. Figure 1 illustrates the locations of the dual-Doppler radar network, the automatic weather station (AWS) network, and the sounding stations. The two radars are S-band radars with $10-\mathrm{cm}$ wavelength and approximately $1^{\circ}$ beamwidth. The radar parameters are similar to those of Weather Surveillance Radar-1988s (WSR-88D), so are the operation modes. In this case, the two radars operated in Volume Coverage Pattern (VCP) 21 mode. A volume scan is composed of nine constant
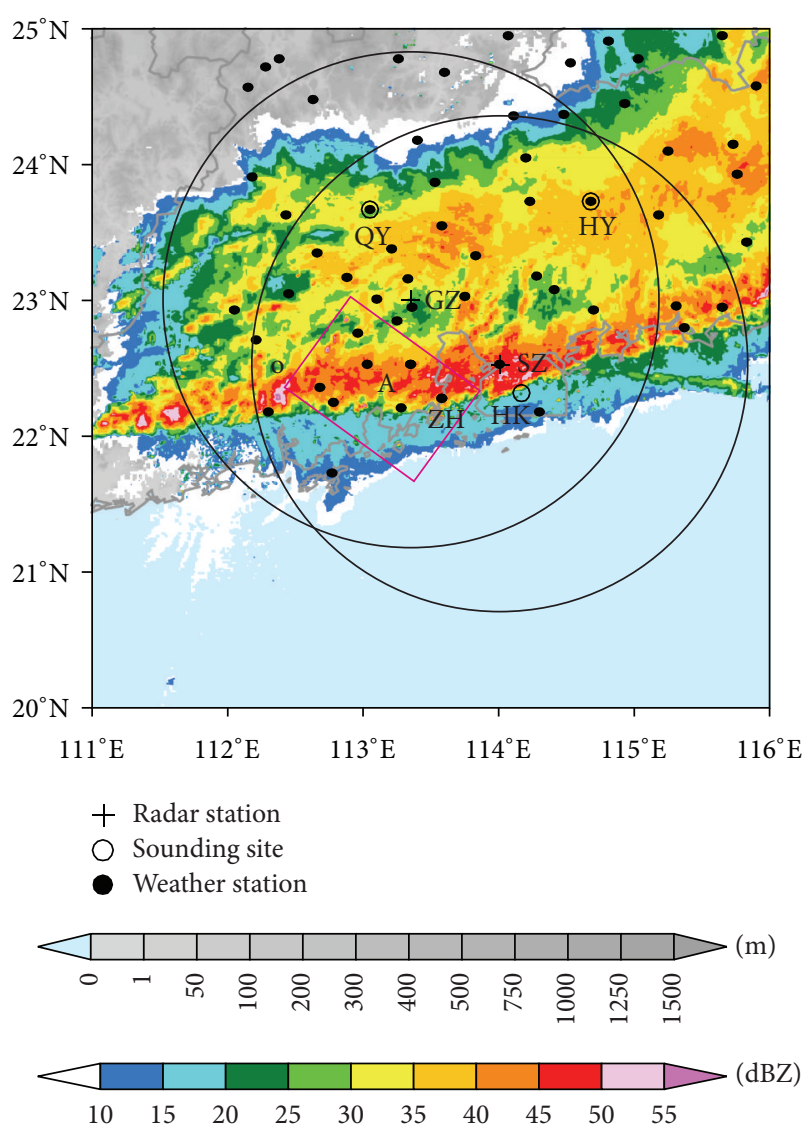

FIGURE 1: Map of the dual-Doppler radar observation network and the mesonet weather stations. The colour shading shows the composite reflectivity (dBZ) on 1017 LST 24 April 2007 and the gray shading for the altitude $(\mathrm{m})$. The two large circles represent Guangzhou (GZ) and Shenzhen (SZ) radars scan domains, respectively. Rectangle A shows the dual-Doppler wind retrieval domain, and "o" indicates the origin of the wind retrieval coordinate system. $\mathrm{ZH}$ represents Zhuhai weather station.

elevations which vary from $0.5^{\circ}$ to $19.5^{\circ}$, and the temporal resolution is approximately $5.5 \mathrm{~min}$.

First, the raw radar data quality control was processed by the software system [48]. The data quality control included removing noise, clutter, and other incorrect values of radar reflectivity and radial velocity with the methods similar to [49]. The automated 2D multipass radial velocity dealiasing scheme has been applied to correct velocity fields [50]. Then, the reflectivity mosaic data was generated by the mosaic system [51]. The reflectivity fields from individual radars in the radar spherical coordinate were remapped into a common Cartesian grid by bilinear interpolation firstly. The remapped reflectivity fields from multiple radars were then merged to produce a unified 3D reflectivity grid. If the grid cell was covered by one radar only, the analysis value from that radar was assigned to the grid cell. If the grid cell was covered by two or more than two radars, the multiple-radar analysis values were merged to the grid cell by weighting method. The weight was based on the distance between an individual grid cell and the radar location as described in [52]. The 3D wind 
fields were retrieved by the multiple-Doppler synthesis and continuity adjustment technique (MUSCAT) from the dualradar data. Bousquet and Chong proposed the MUSCAT to retrieve 3D wind field using an airborne Doppler radar [53]. The comparative study with the extended overdetermined dual-Doppler (EODD) applications shows that MUSCAT provides the more regular description of the airflow. Numerical tests definitely reveal the real improvements of MUSCAT in Doppler radar data retrieval. The statistics of the errors between the retrieved and simulated $3 \mathrm{D}$ wind components are small. The mean values are less than $0.2 \mathrm{~m} / \mathrm{s}$, while standard deviations remain within $0.7 \mathrm{~m} / \mathrm{s}$ below $12 \mathrm{~km}$ altitude [53]. Chong and Bousquet have optimized this algorithm for ground-based dual-radar retrieval and introduced the complex terrain technology [54]. Now, it is an operational multiple-Doppler wind retrieval system in France [55]. Zhou and Zhang [56] have applied the MUSCAT for groundbased dual-radar wind retrieval and have tested the MUSCAT accuracy using the numerical simulation. The result was the same with the former one [53]. Because the 3D wind field deduced from the MUSCAT in the least squares sense does not rigorously satisfy the air mass continuity equation, in order to improve the vertical velocity estimation, a refinement is processed. The refinement is a posteriori integration of the continuity equation to refine the first estimation of the vertical velocity. It consists of adjusting the boundary condition in order to optimize the vertical velocity, followed by upward integration of the continuity equation [57]. Previously, we investigated the 3D wind field of a heavy precipitation in South China [58], which is not associated with a squall line, and the $3 \mathrm{D}$ structure of a rainfall event along the Meiyu (Baiu, Changma) front [59], using the MUSCAT dualradar retrieval wind. We have revealed that the meso- $\beta$-scale convergence line at the lower and middle altitudes is a cause of the heavy precipitation in both cases. The horizontal scale of this meso- $\beta$-scale convergence line was $40-80 \mathrm{~km}$, and the vertical scale was about $1.5-4.5 \mathrm{~km}$ in altitude.

The origin of the wind retrieval coordinate system is at $112.47^{\circ} \mathrm{E}, 22.37^{\circ} \mathrm{N}$, indicated by "o" in Figure 1. The $x$ axis is parallel to the dual-radar baseline at the direction of $127.3^{\circ}$ from the north, the $y$-axis is perpendicular to the baseline, and the $z$-axis points to the direction opposite to the gravity vector. The grid resolutions are $1 \mathrm{~km}$ in the horizontal direction and $250 \mathrm{~m}$ in the vertical direction. The surface mesonet consists of the AWSs established by the CMA. Two rawinsonde stations are located near the dual-radar network. One is in Qingyuan and the other in Hong Kong.

\section{Results}

\subsection{Synoptic Condition and Environmental Feature}

3.1.1. Synoptic Condition. At 2000 local standard time (LST) 23 April 2007, a temperature trough was showed along Chongqing, Guizhou, and Guangxi provinces at $850 \mathrm{hPa}$. The region of the squall initiation after 8 hours was ahead of the temperature trough. A pressure trough was over Guangxi, Hunan, and Jiangxi provinces, and the squall line initiation region was on the south of it. The warm, moist southwest wind from South China Sea prevailed in a widespread area ahead of the pressure trough. At $700 \mathrm{hPa}$, a low-level jet (LLJ) with a maximum speed of $18 \mathrm{~m} / \mathrm{s}$ prevailed over Guangxi and Guangdong provinces in front of the pressure trough. Behind the trough, the winds were from the northwest with low wind speed. Abundant moisture was available in a wide area ahead of the trough with dewpoint depression of more than $4^{\circ} \mathrm{C}$. At $500 \mathrm{hPa}$, a shallow trough was shown along Chongqing and Sichuan provinces. The west wind prevailed above the LLJ of $700 \mathrm{hPa}$. The wind speed was more than $20 \mathrm{~m} / \mathrm{s}$ over Guangxi and Guangdong provinces. At $200 \mathrm{hPa}$, a region of divergence occurred over Guangdong province. The contribution of divergence in the upper troposphere contributed to the upward motion in the warm region [43]. At 0200 LST 24 April, a quasi-stationary front was extended from China west to Japan with large latitudinal gradient of potential temperature and equivalent potential temperature at $850 \mathrm{hPa}$. The south wind was on the south of the front and north wind on the north of it. The squall line area was on the south side of the front. A transversal trough laid at $500 \mathrm{hPa}$ in north China (line $\mathrm{AB}$ in Figure 2(a)). The shallow trough was still shown along Chongqing and Sichuan (line CD in Figure 2(a)). By 0800 LST, a pressure trough was in the south of Guangxi and Guangdong at $850 \mathrm{hPa}$. A convergence line was located on the south part of Guangxi, Guangdong, and Fujian provinces. The southwesterly wind prevailed on the south side of the convergence line, and the northwesterly wind was observed on the north of it. The convergence line was also shown at $700 \mathrm{hPa}$. The LLJ prevailed with the maximum speed of $30 \mathrm{~m} / \mathrm{s}$ over Guangxi and Guangdong. At $500 \mathrm{hPa}$, the two troughs moved southward (Figure 2(b)). The wind over Guangxi and Guangdong provinces was from west. This configuration was conducive to convective system development.

3.1.2. Presquall and Postsquall Conditions. The vertical structure of the atmospheric environment was deduced from the sounding data. Qingyuan and Hong Kong soundings at 0800 LST 24 April were chosen. The former is in the trail of the squall line and the latter in the front-to-rear inflow region of the squall line. Figure 3 shows the skew T-lnP diagram of Hong Kong sounding. The storm-relative wind hodographs of Qingyuan and Hong Kong sounding are illustrated in Figure 4. To calculate the storm-relative motion, it separately averaged the $u$ and $v$ components of the wind at all levels. Then, it added the mean $u$ and $v$ vectors. As shown in Figure 3, the lifting condensation level (LCL) was at $986 \mathrm{hPa}$ and the convective condensation level (CCL) at $960 \mathrm{hPa}$. The level of free convection (LFC) was low with $946 \mathrm{hPa}$ height. The equilibrium temperature level (ETL) was at $218 \mathrm{hPa}$. Horizontal winds veered with height below $700 \mathrm{hPa}$, which indicates warm air advection in the lower troposphere. The southwesterly flow from the South China Sea prevailed at the lower levels with adequate water vapour, while the northwesterly wind from the mainland with cold and dry air prevailed at the upper levels. The vertical shear was about $18 \times 10^{-3} \mathrm{~s}^{-1}$ between the 0 and $3 \mathrm{~km}$ altitudes and $23 \times 10^{-3} \mathrm{~s}^{-1}$ between the 0 and $5 \mathrm{~km}$ altitudes. The moisture was abundant at the lower levels, with the relative humidity below $800 \mathrm{hPa}$ being approximately 


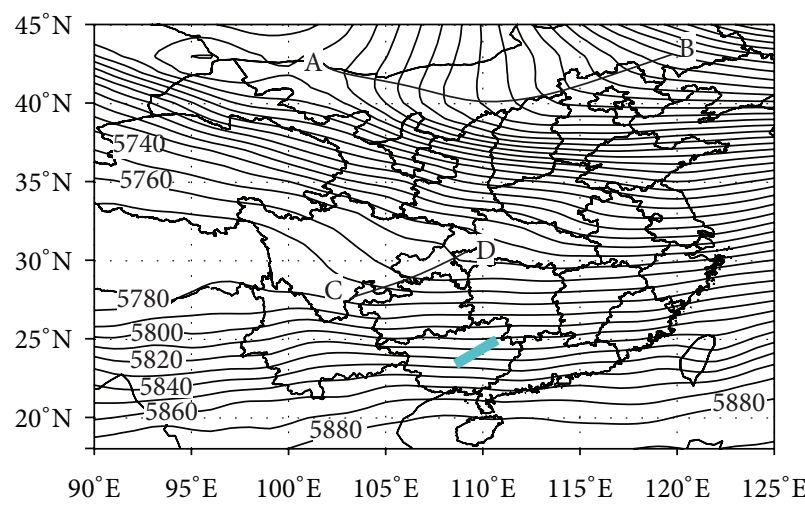

(a)

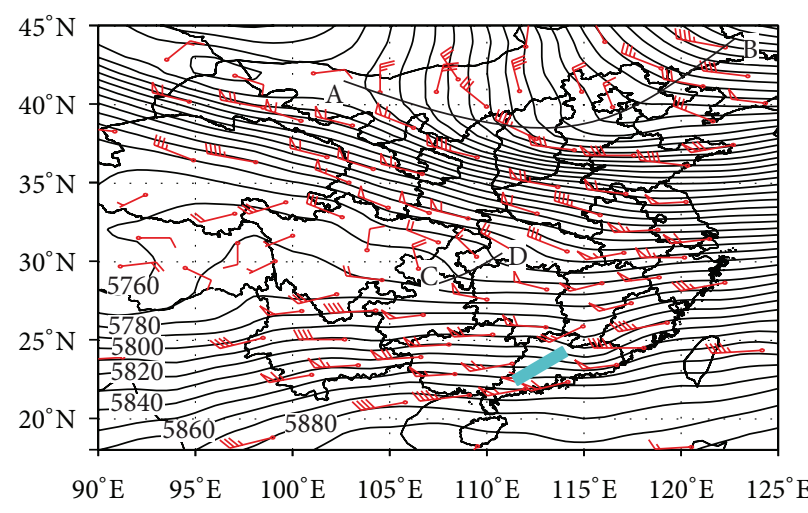

(b)

FIgURE 2: National Centers for Environment Prediction (NCEP) geopotential height analyses at $500 \mathrm{hPa}$ from 0200 LST (a) and 0800 LST (b) 24 April 2007. The blue rectangles indicate the position of the squall line and the thick solid lines are for the trough.

RH (\%)

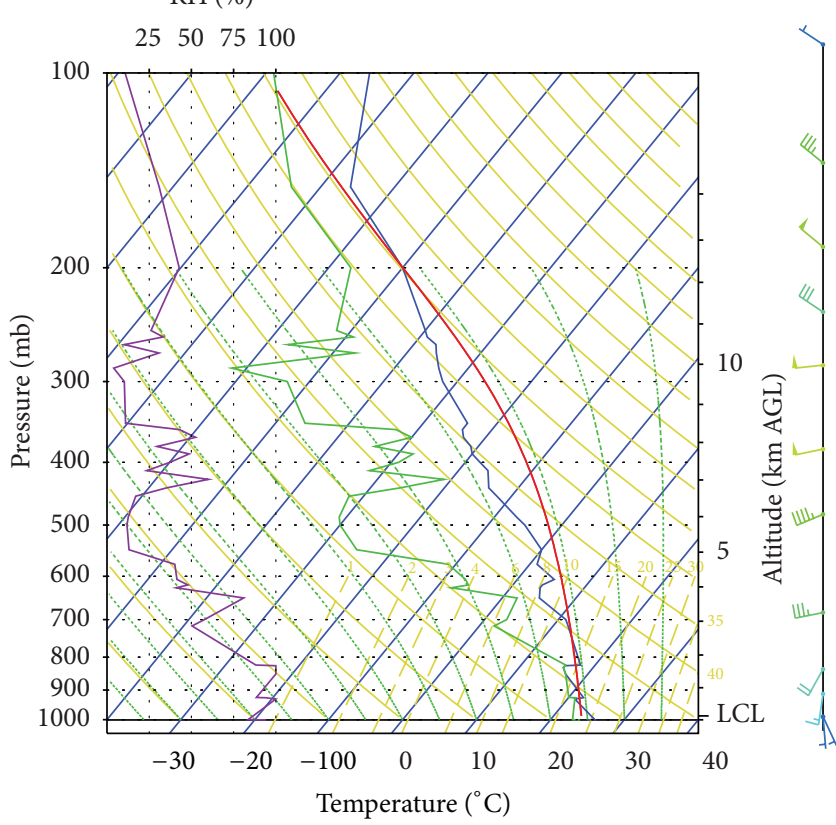

FIGURE 3: Skew T-lnP diagram of Hong Kong sounding released at 0800 LST 24 April 2007. Each half barb indicates 5 knots; each full barb, 10 knots; and each flag, 50 knots $(1 \mathrm{knot}=0.514 \mathrm{~m} / \mathrm{s})$. The lifting condensation level (LCL) is indicated. The relative humidity is given in the left panel.

$85 \%$. There was a convective instability below $3 \mathrm{~km}$. The warm south air contributed to the convective instability. The value of the convective available potential energy (CAPE) was approximately $1676 \mathrm{~J} / \mathrm{kg}$. The large CAPE denotes that the presquall environment was convectively unstable and was favourable for squall line development. The water vapour mixing ratio $(q)$ was large below $823 \mathrm{hPa}$, with a value of $13.87 \mathrm{~g} / \mathrm{kg}$ at this level. It was $6.16 \mathrm{~g} / \mathrm{kg}$ at $716 \mathrm{hPa}$ and $0.72 \mathrm{~g} / \mathrm{kg}$ at $546 \mathrm{hPa}$ (about $5 \mathrm{~km}$ altitude). The profile of equivalent potential temperature $(\theta e)$ in the presquall line environment showed convective instability below $625 \mathrm{hPa}$. The equivalent

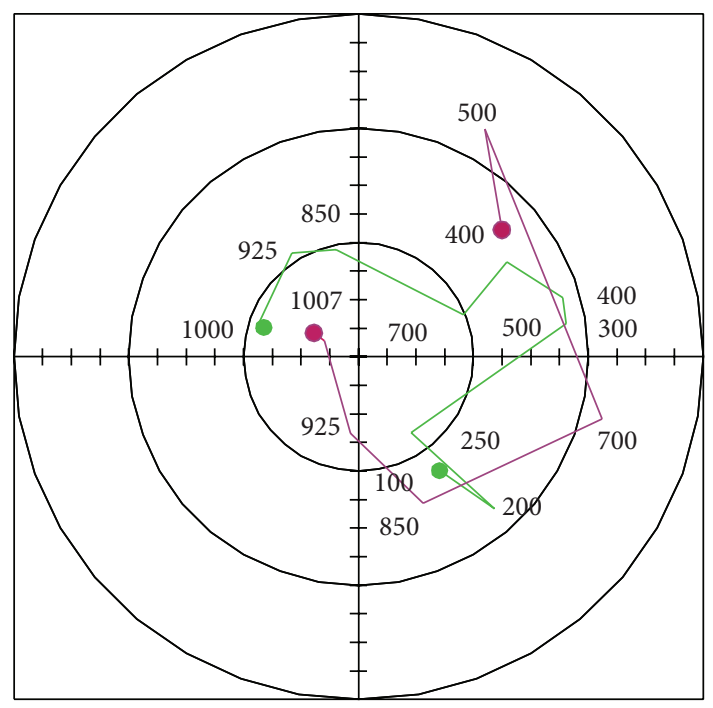

FIGURE 4: Storm-relative wind hodograph from the upstream sounding (Qingyuan: magenta line) and downstream sounding (Hong Kong: green line) at 0800 LST 24 April 2007. Every ring presents 20 knots of increment in speed, and the numbers indicate the pressure levels (hpa).

potential temperature had a maximum value of $352 \mathrm{~K}$ at the surface and had a minimum value of $327 \mathrm{~K}$ at $625 \mathrm{hPa}$. The difference was $25 \mathrm{~K}$, which was larger than that of the other subtropical squall line [43]. At the same time, Qingyuan is in the stratiform cloud region. Its CAPE value was only $11 \mathrm{~J} / \mathrm{kg}$. The LFC in Qingyuan was at $609 \mathrm{hPa}$ and the ETL at $579 \mathrm{hPa}$. The relative humidity in Qingyuan was small compared with that in Hong Kong.

3.1.3. Surface Observations. By 0200 LST 24 April, the surface map showed a mesolow in the northwest region of Guangdong that the squall line was initiation. A weak temperature trough was indicated in the vicinity of Hunan and Guangxi. The temperature ahead of the trough was warmer. A convergence line was shown at the northwest region of Guangdong 

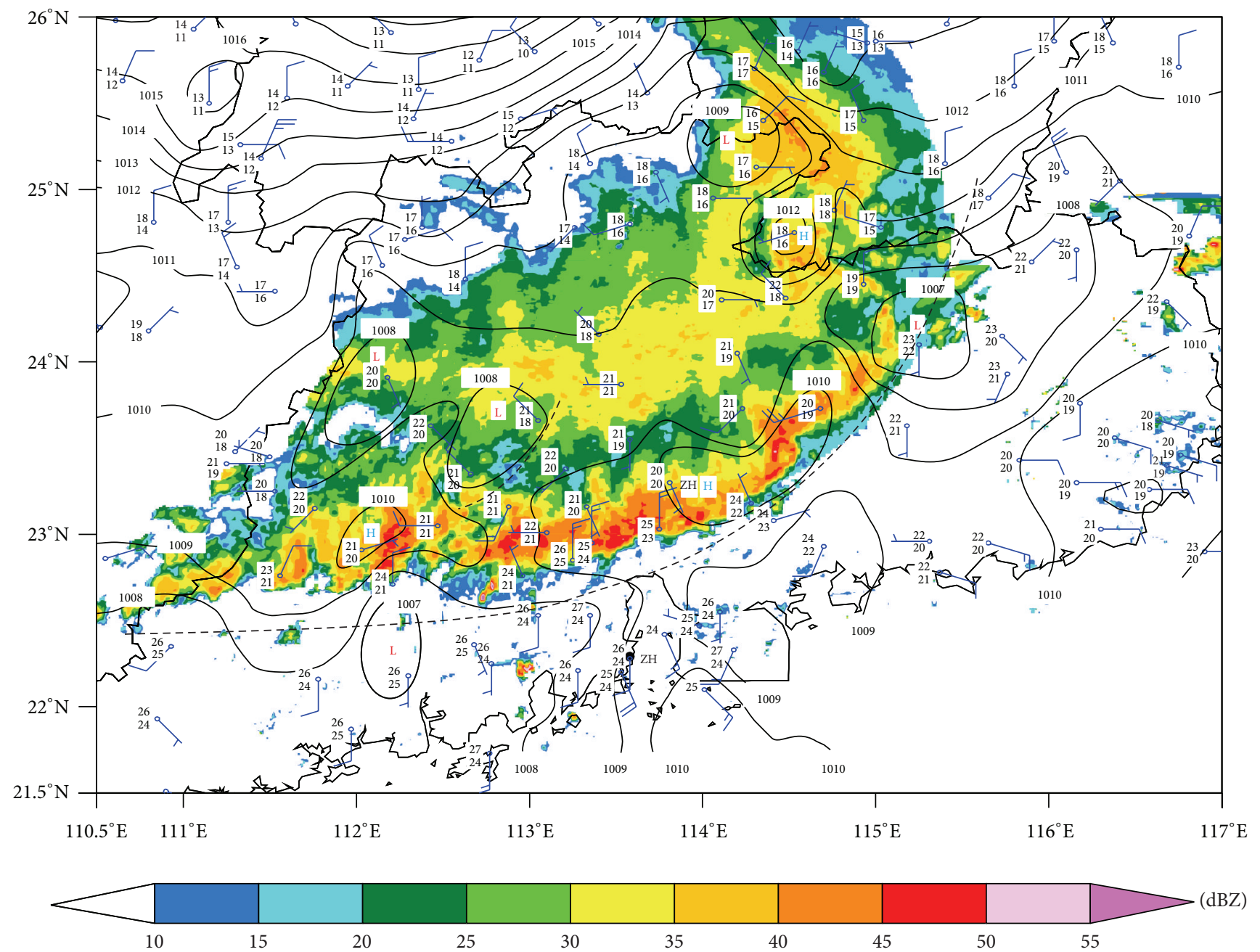

FIGURE 5: Surface chat at 0800 LST 24 April 2007. The colour shading is radar reflectivity (dBZ) at $2 \mathrm{~km}$ height. Solid contours are pressure field $(\mathrm{hPa})$. Dashed lines indicate the two surface convergence lines. Temperature and dew point $\left({ }^{\circ} \mathrm{C}\right)$ are given at individual weather station.

and moved southeastward. The squall line developed along the convergence line. As indicated in Figure 5, a surface convergence line was presented along the leading edge. The southerly wind from the South China Sea was warm and humid. It was dominant ahead of the convergence line. The northerly flow prevailing in the rear of the convergence line was cold. A weak presquall mesoscale low $(1007 \mathrm{hPa})$ was located on the southwest side of the leading edge. Two thunderstorm mesohighs $(1010 \mathrm{hPa})$, resulting from the cool convective outflow, can be seen along the convective line with heavy precipitation. The weak mesolows were at the back edge of the stratiform precipitation region. The surface backward flow and the environment flow converged, resulting in the convergence line (the short dashed-line in Figure 5) at the front of the weak low center. The horizontal temperature gradient reached a high value across the squall front.

Figure 6 demonstrates the time series of the surface observations at Zhuhai station from 0800 to 1400 LST 24 April 2007. Before the squall line arrival, the temperature and the dew point decreased by approximately $1^{\circ} \mathrm{C}$. The relative humidity dropped by $3 \%$. The wind speed steadied around
$2.3 \mathrm{~m} / \mathrm{s}$, and the wind direction remained between $180^{\circ}$ and $200^{\circ}$. The pressure slowly increased when the squall line approached. The squall front arrived in Zhuhai at 1015 LST. In a few minutes, the temperature and dew point dropped by approximately $3^{\circ} \mathrm{C}$ and $2^{\circ} \mathrm{C}$, respectively. The relative humidity dropped by $3 \%$ rapidly, and the pressure increased by approximately $1.4 \mathrm{mb}$. The wind direction rotated from south to northeast, with a wind gust of $6 \mathrm{~m} / \mathrm{s}$. The precipitation rate reached a peak value of $31 \mathrm{~mm} / \mathrm{h}$ between 1000 and 1100 LST. The strongest precipitation was $8.7 \mathrm{~mm}$ from 1024 to 1030 LST. The accumulative precipitation between 1000 and 1200 LST was $56.8 \mathrm{~mm}$. After $1200 \mathrm{LST}$, the meteorological parameters were changed as follows. The temperature tended to be uniform at $21^{\circ} \mathrm{C}$ over a period of $3 \mathrm{~h}$, and the dew point was at $20.5^{\circ} \mathrm{C}$. The pressure decreased to $1010.8 \mathrm{hPa}$ on $1215 \mathrm{LST}$ and increased to $1011.5 \mathrm{hPa}$ on $1300 \mathrm{LST}$. After 30 minutes, it decreased to $1010.3 \mathrm{hPa}$ and increased to $1011 \mathrm{hPa}$ on 1400 LST. The wind speed kept an approximate direction of $120^{\circ}$ with a mean value of $4 \mathrm{~m} / \mathrm{s}$ between 1200 and 1300 LST and then decreased slowly. At the same time, the precipitation rate decreased markedly with a rate close to $1.6 \mathrm{~mm} / \mathrm{h}$ at 


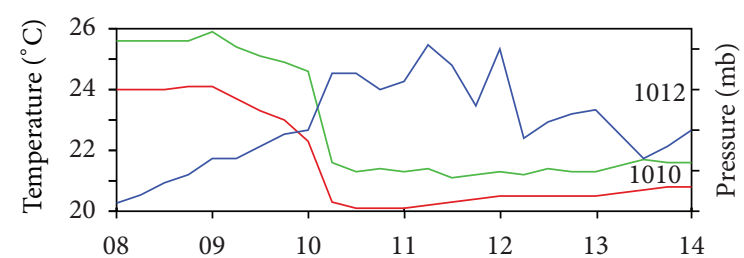

(a)

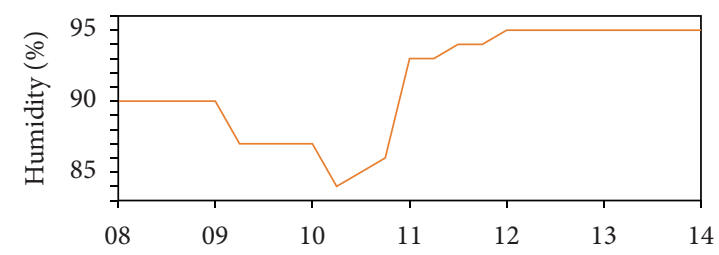

(b)

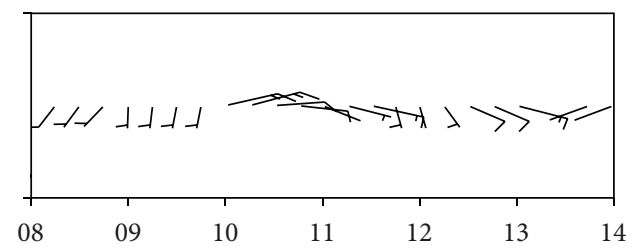

(c)

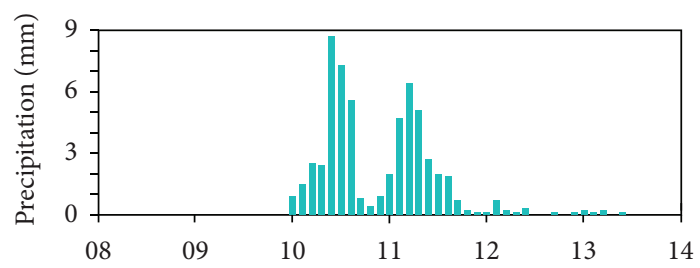

(d)

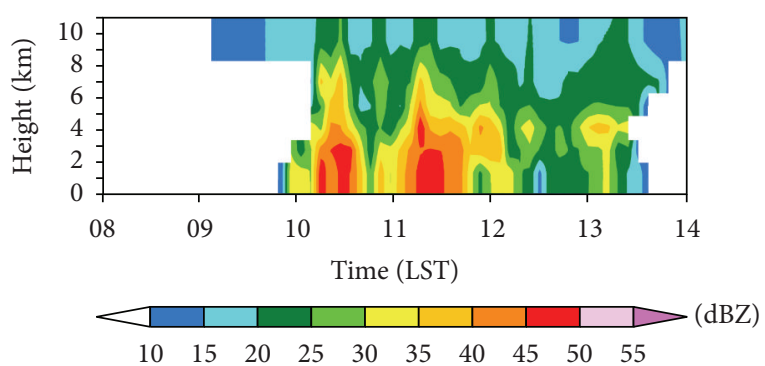

(e)

Figure 6: Time series of Zhuhai weather station temperature $\left({ }^{\circ} \mathrm{C}\right.$, green line (a)), dew point $\left({ }^{\circ} \mathrm{C}\right.$, red line $\left.(\mathrm{a})\right)$, pressure $(\mathrm{mb}$, blue line (a)), relative humidity (\%, yellow line (b)), and wind ( $\mathrm{m} / \mathrm{s}(\mathrm{c})$ ) every $15 \mathrm{~min}$; precipitation every $6 \mathrm{~min}(\mathrm{~mm}$, bar graphs $(\mathrm{d}))$ between 0800 and 1400 LST 24 April 2007. (e) Time-height cross-section of the reflectivity (dBZ) every $5.5 \mathrm{~min}$ at Zhuhai station observed by Guangzhou radar.

1300 LST. The relative humidity at the surface increased to $95 \%$ at $1200 \mathrm{LST}$ as a result of the precipitation. This sequence of the meteorological events was the typical feature at the passage of a squall line $[1,2,9,43,46]$.

Figure 6(e) illustrates the time-height cross-section reflectivity at Zhuhai station observed by Guangzhou radar. In this study, the convective cell was defined as the cell with

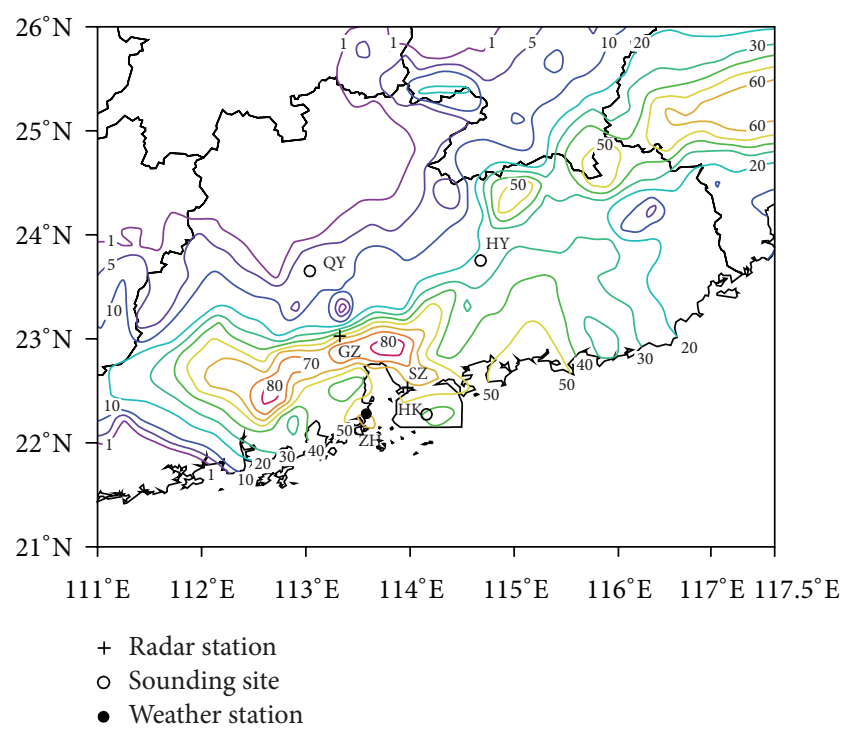

Figure 7: Accumulative precipitation contours at 1, 5, 10, 20, 30, $40,50,60,70$, and $80 \mathrm{~mm}$ from weather stations between 0800 and 1400 LST 24 April 2007.

radar reflectivity of over $40 \mathrm{dBZ}$. The stratiform region was defined as the wide region with the moderate radar reflectivity (30 to $40 \mathrm{dBZ}$ ) [3]. Two convective cells passed through Zhuhai station one after another. The first convective cell was more than $4.5 \mathrm{~km}$ thick. The core with the reflectivity of over $45 \mathrm{dBZ}$ was about $3 \mathrm{~km}$ thick. It lasted for approximately half an hour and produced the first precipitation peak (a peak at 10:20-10:45). The second cell was about $6 \mathrm{~km}$ in height, and the core was close to $3 \mathrm{~km}$ thick. It produced the second precipitation peak (a peak at 11:10-11:45). The figure shows clearly that the two convective cells resulted in the intense precipitation.

The squall line produced the intense precipitation in a short time in the south part of Guangdong province. The AWS observations showed clearly that the accumulative precipitation in $6 \mathrm{~h}$ was more than $20 \mathrm{~mm}$ over a large region (Figure 7 ). There were two heavy precipitation centers with the precipitation of more than $70 \mathrm{~mm}$ around the Pearl River Delta. The precipitation in Zhuhai city was $59 \mathrm{~mm}$ in $6 \mathrm{~h}$. The precipitation from 1000 to 1200 LST was $56.8 \mathrm{~mm}$ in Zhuhai. It also revealed that the precipitation by the squall line was intense and short-lived.

3.2. Evolution of the Mesoscale System. The reflectivity mosaic data with five Doppler weather radars is used for investigating the evolution of the squall line. These radars are all CINRAD/SA, located in Guangzhou (GZ), Shaoguan (SG), Shantou (ST), Shenzhen (SZ), and Yangjiang (YJ). Figure 8 illustrates the mosaic data at $2.5 \mathrm{~km}$ and AWSs wind from 0400 to 1300 LST 24 April 2007. $2.5 \mathrm{~km}$ is a representative altitude that is free from terrain effect.

At 0400 LST, a southwest-northeast echo band with $35 \mathrm{dBZ}$ developed in the adjacent region between Guangxi and Guangdong provinces (Figure $8(\mathrm{a})$ ). The strong cells of over $50 \mathrm{dBZ}$ were observed in the echo band. Some 


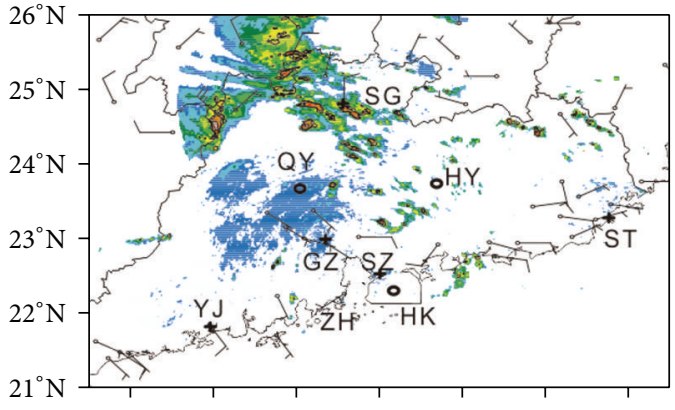

$111^{\circ} \mathrm{E} \quad 112^{\circ} \mathrm{E} \quad 113^{\circ} \mathrm{E} \quad 114^{\circ} \mathrm{E} \quad 115^{\circ} \mathrm{E} \quad 116^{\circ} \mathrm{E} \quad 117^{\circ} \mathrm{E}$

+ Radar station

Sounding site

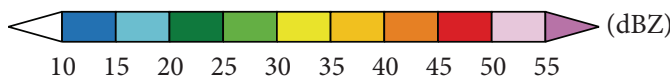

(a) 0400 LST

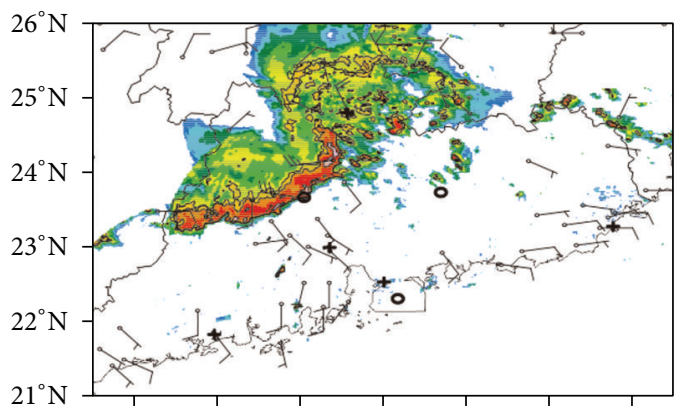

$111^{\circ} \mathrm{E} \quad 112^{\circ} \mathrm{E} \quad 113^{\circ} \mathrm{E} \quad 114^{\circ} \mathrm{E} \quad 115^{\circ} \mathrm{E} \quad 116^{\circ} \mathrm{E} \quad 117^{\circ} \mathrm{E}$

+ Radar station

Sounding site

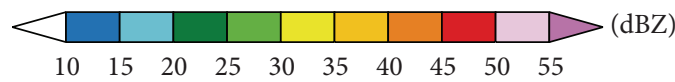

(c) 0600 LST

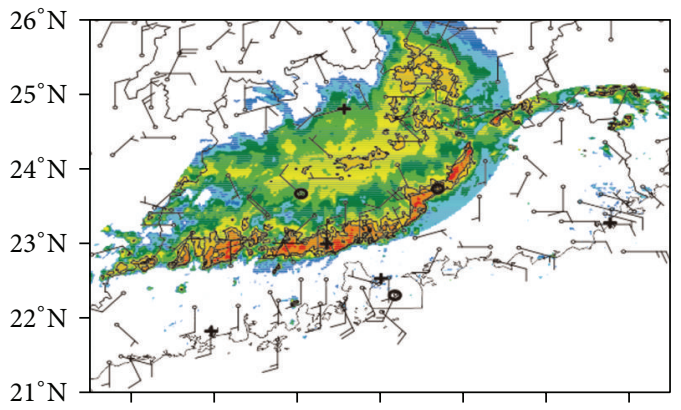

$111^{\circ} \mathrm{E} \quad 112^{\circ} \mathrm{E} \quad 113^{\circ} \mathrm{E} \quad 114^{\circ} \mathrm{E} \quad 115^{\circ} \mathrm{E} \quad 116^{\circ} \mathrm{E} \quad 117^{\circ} \mathrm{E}$

+ Radar station

Sounding site

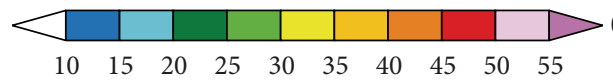

(e) 0800 LST

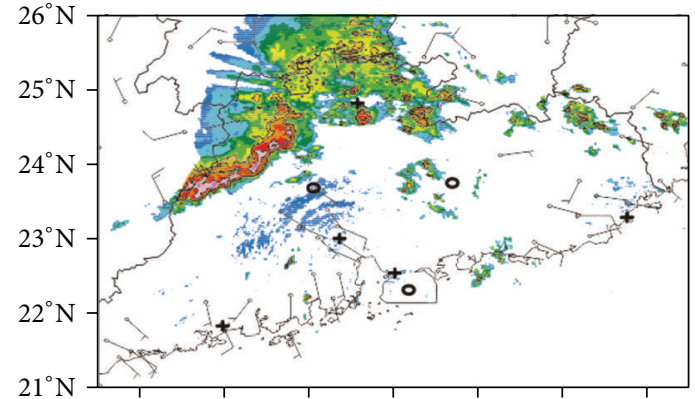

$111^{\circ} \mathrm{E} \quad 112^{\circ} \mathrm{E} \quad 113^{\circ} \mathrm{E} \quad 114^{\circ} \mathrm{E} \quad 115^{\circ} \mathrm{E} \quad 116^{\circ} \mathrm{E} \quad 117^{\circ} \mathrm{E}$

+ Radar station

Sounding site

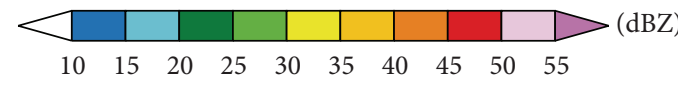

(b) 0500 LST

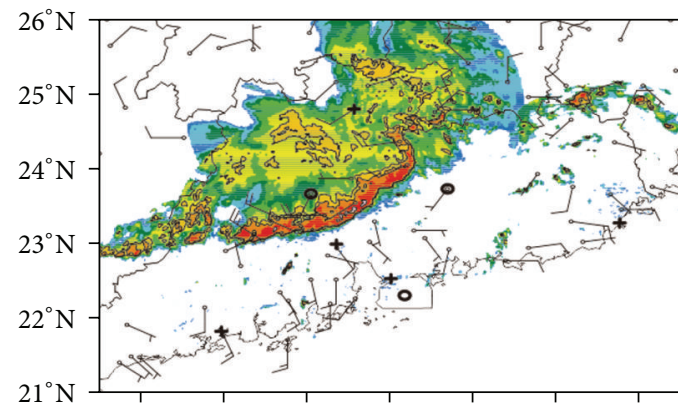

$111^{\circ} \mathrm{E} \quad 112^{\circ} \mathrm{E} \quad 113^{\circ} \mathrm{E} \quad 114^{\circ} \mathrm{E} \quad 115^{\circ} \mathrm{E} \quad 116^{\circ} \mathrm{E} \quad 117^{\circ} \mathrm{E}$

+ Radar station

Sounding site

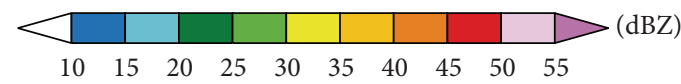

(d) 0700 LST

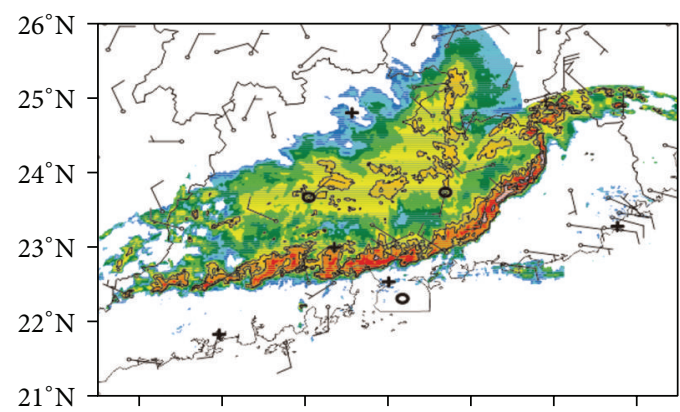

$111^{\circ} \mathrm{E} \quad 112^{\circ} \mathrm{E} \quad 113^{\circ} \mathrm{E} \quad 114^{\circ} \mathrm{E} \quad 115^{\circ} \mathrm{E} \quad 116^{\circ} \mathrm{E} \quad 117^{\circ} \mathrm{E}$

+ Radar station

Sounding site

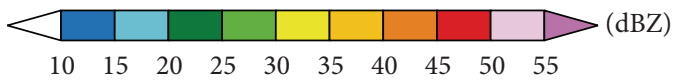

(f) 0900 LST

Figure 8: Continued. 


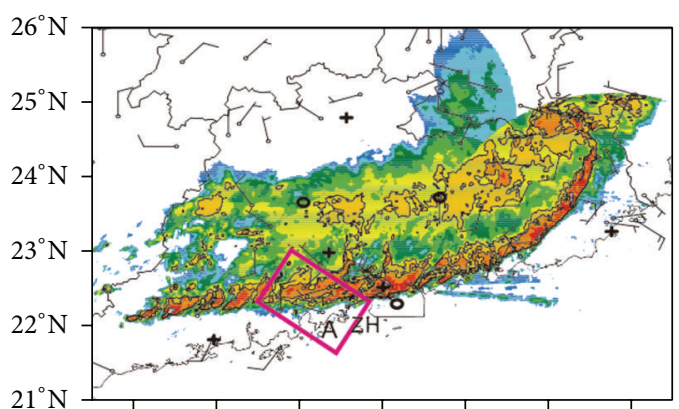

$111^{\circ} \mathrm{E} \quad 112^{\circ} \mathrm{E} \quad 113^{\circ} \mathrm{E} \quad 114^{\circ} \mathrm{E} \quad 115^{\circ} \mathrm{E} \quad 116^{\circ} \mathrm{E} \quad 117^{\circ} \mathrm{E}$

+ Radar station

Sounding site

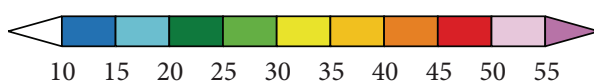

(g) 1000 LST
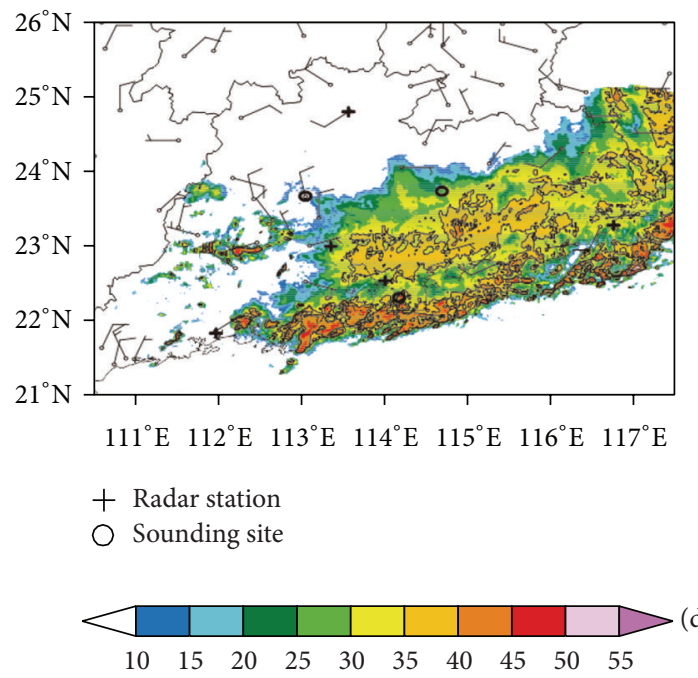

(i) 1200 LST
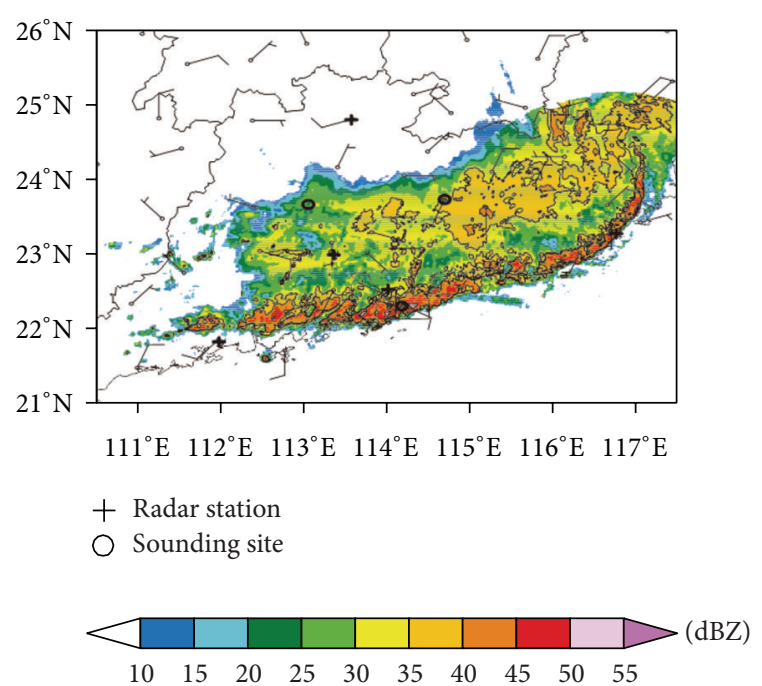

(h) 1100 LST
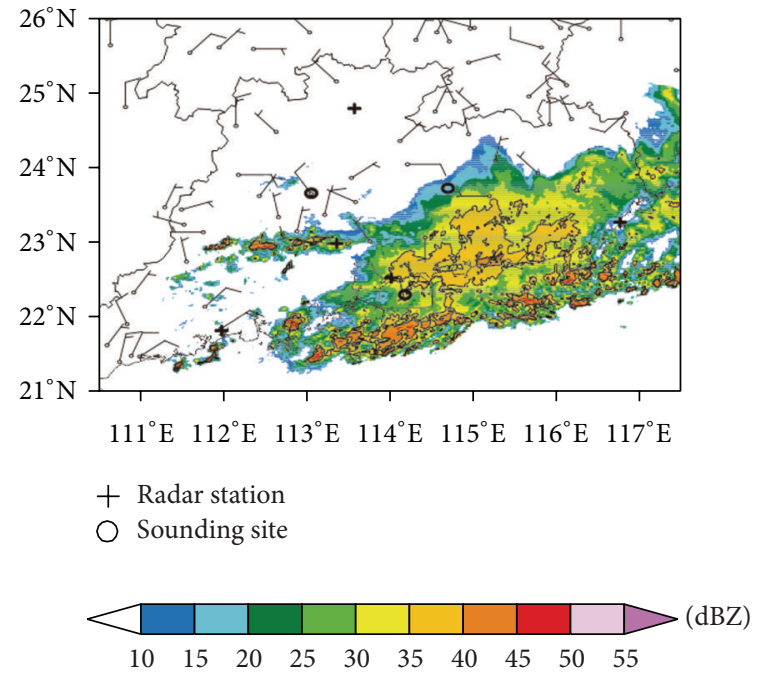

(j) 1300 LST

Figure 8: Radar reflectivity mosaic data at $2.5 \mathrm{~km}$ altitude and the surface wind field between 0400 and 1300 LST 24 April 2007. Rectangle A in $(\mathrm{g})$ shows the dual-Doppler wind retrieval domain. The contours are $35 \mathrm{dBZ}, 40 \mathrm{dBZ}$, and $50 \mathrm{dBZ}$.

intense cells developed around Shaoguan radar station. Both the strong cells and the echo band developed quickly and moved southeastward (Figure 8(b)). The maximum reflectivity embedded in the convective cloud was over $55 \mathrm{dBZ}$. After one hour (Figure 8(c)), the leading edge arrived at Qingyuan station. The surface wind speed at Qingyuan station was more than $12 \mathrm{~m} / \mathrm{s}$. Some intense cells with $50 \mathrm{dBZ}$ lined up along the leading edge. The squall line continued to move southeastward. At 0700 LST (Figure 8(d)), the squall line was more than $250 \mathrm{~km}$ in length in the west-east direction. The rear of the squall line was the wide stratiform region with the moderate radar reflectivity ( 30 to $40 \mathrm{dBZ}$ ), while the leading edge was a narrow convective region of over $30 \mathrm{dBZ}$. Between the stratiform region and the convective region, a narrow weak reflectivity band under $30 \mathrm{dBZ}$ formed. It was similar to the reflectivity trough [3]. A convergence line was located at the surface. At the front part of the squall line, the southerly wind prevailed. On the other hand, the northwesterly wind was observed behind the squall front. The convective cloud was developing quickly in the convergence area. The squall line moved southeastward and passed through Heyuan sounding station and Guangzhou radar station (Figure 8(e)). The surface convergence line moved southeastward, too. The wind speeds at the two stations exceeded $10 \mathrm{~m} / \mathrm{s}$ and $6 \mathrm{~m} / \mathrm{s}$, respectively. The squall line developed continually. It was more than $500 \mathrm{~km}$ in length in the west-east direction at 0900 LST (Figure 8(f)). Seven intense cells of over $50 \mathrm{dBZ}$ were shown at its front. The rear stratiform region broadened. At 1000 LST (Figure $8(\mathrm{~g})$ ), the squall line moved into the dual-Doppler radar wind retrieval domain and continued to develop. Its length was approximately $600 \mathrm{~km}$ in the westeast direction. The asymmetric cloud structure of the squall line was clear. The stratiform cloud continued to broaden in the east part of the squall line. On the other hand, the 


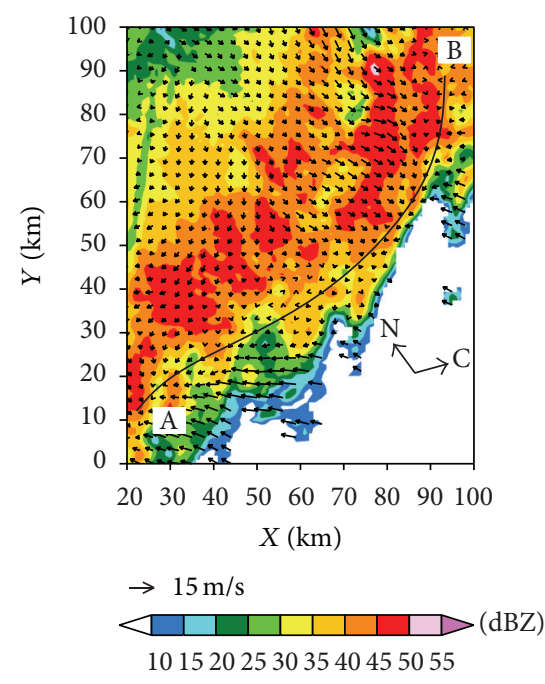

(a)

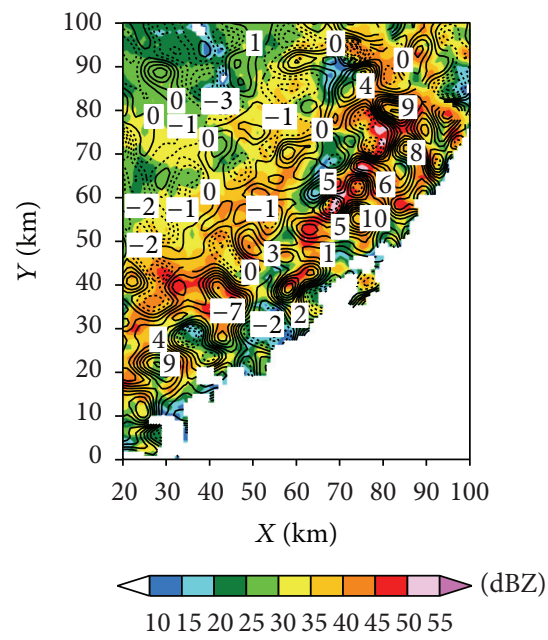

(d)

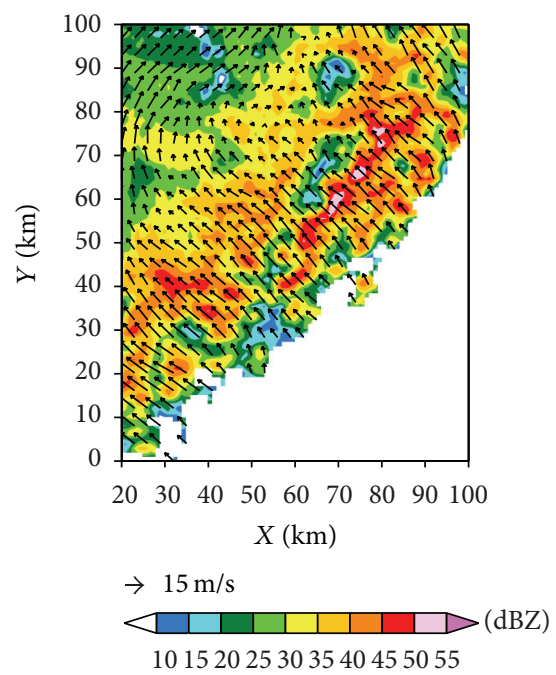

(b)

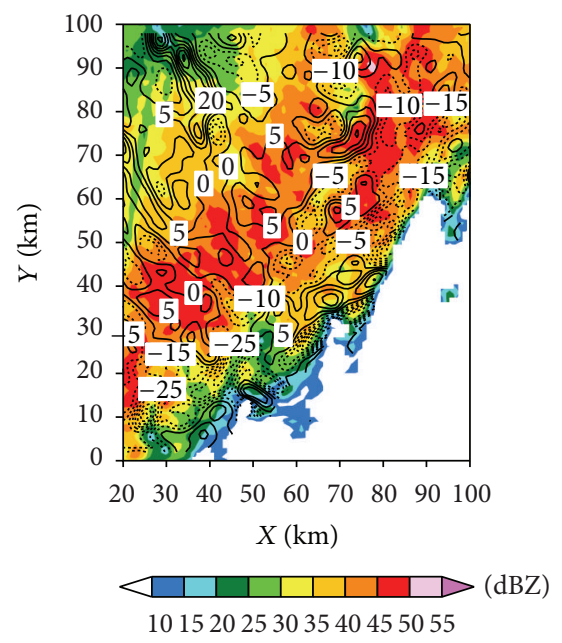

(e)

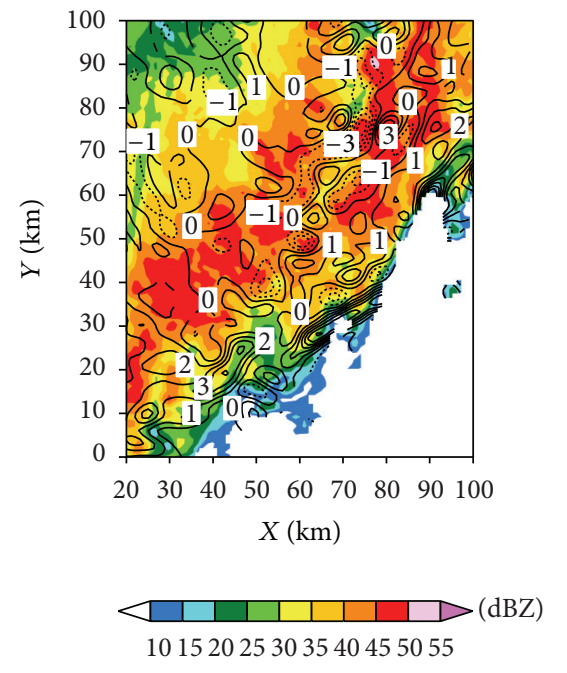

(c)

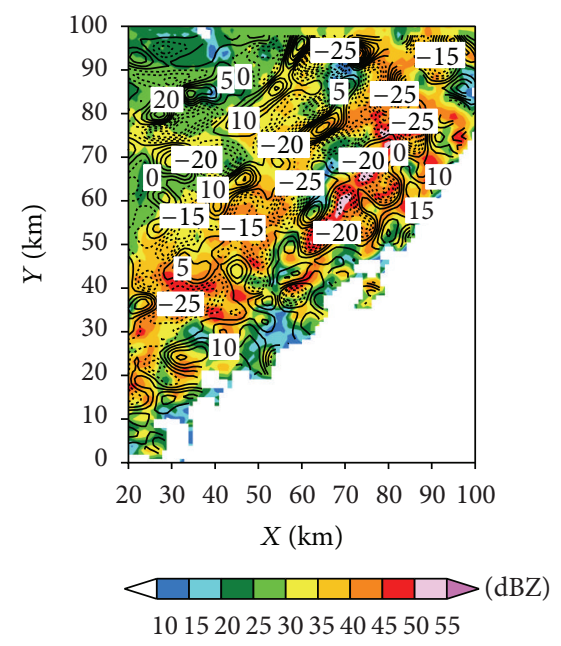

(f)

Figure 9: (a-b) The storm-relative horizontal wind fields at 1.75 and $5 \mathrm{~km}$, respectively, at 1005 LST 24 April 2007. (c-d) The vertical velocities at 1.75 and $5 \mathrm{~km}$, respectively. The solid lines indicate the updraft and the dashed lines for the downdraft. (e-f) The divergence field $\left(10^{-4} \mathrm{~s}^{-1}\right.$ ) at 1.75 and $5 \mathrm{~km}$, respectively. Solid lines are for positive values (divergence) and dashed lines for negative value (convergence); the contour interval is $5 \times 10^{-4} \mathrm{~s}^{-1}$. The $x$-axis and $y$-axis are, respectively, parallel and perpendicular to the radar baseline. The colour shading is radar reflectivity (dBZ). The squall line movement direction $(\mathrm{C})$ and the north $(\mathrm{N})$ are indicated in (a). Line AB in (a) denotes the convergence line.

stratiform cloud in the west part of the squall line (the region around Qiangyuan station) was relatively weak. At 1100 LST (Figure 8(h)), the squall front moved to the south part of the dual-radar retrieval domain. As illustrated in Figures 8(i) and $8(j)$, the squall line moved to the South China Sea with weak reflectivity compared with the former one finally.

3.3. Dual-Doppler Analysis. The 3D wind fields were retrieved by the MUSCAT using Guangzhou-Shenzhen dual-Doppler synchronous volume scan data. At the time of the analysis (1000 to 1041 LST), the squall line was moving at a nearly constant speed of $12 \mathrm{~m} / \mathrm{s}$ in the direction of $112.5^{\circ}$. The mean motion was deduced from the reflectivity data in the successive volume scans by Guangzhou radar. The storm-relative horizontal wind was subsequently calculated by subtracting the squall line propagation velocity from the dual-Doppler retrieval wind.

3.3.1. Wind Field on the Horizontal Plane. Figure 9 presents the radar reflectivity and storm-relative wind field at 1005 LST 24 April 2007. At the lower altitudes, the leading edge was oriented in the southwest-northeast direction. Eight intense cells of over $45 \mathrm{dBZ}$ were located along the leading edge at the altitude of $1.75 \mathrm{~km}$ (Figure $9(\mathrm{a})$ ). The maximum reflectivity was over $50 \mathrm{dBZ}$ in the northeast part of the leading edge.

The storm-relative front-to-rear horizontal inflow and the storm-relative rear-to-front cold inflow were illustrated in Figure 9(a). The storm-relative front-to-rear horizontal inflow was in the right of the convergence line (line $A B$ in Figure 9(a)) and prevailed at the leading edge. The region of 
large presquall line wind vectors was located at $x<60 \mathrm{~km}$. Wind vectors were nearly paralleling the line at a small angle intercepting the squall line. The strongest inflow was about $17 \mathrm{~m} / \mathrm{s}$. The reflectivity gradient was intense at the leading edge. The storm-relative rear-to-front cold inflow was in the left of the convergence line. The two flows eventually converged at the convective line (line $\mathrm{AB}$ in Figure 9(a)), resulting in the updraft (Figure $9(\mathrm{c})$ ) and convergence band (Figure 9(e)). Some convergence centers were observed in the convergence band (Figure 9(e)). The absolute value of the strongest convergence was more than $30 \times 10^{-4} \mathrm{~s}^{-1}$. Above $3 \mathrm{~km}$, the storm-relative front-to-rear horizontal inflow was stronger than that of the low levels at the leading edge.

The surface observation at 1000 LST (Figure 8(g)) indicated that the southerly flow prevailed on the front part of the squall line. On the other hand, the northwesterly flow was observed in the stratiform region. On the whole, the dualDoppler retrieval at the lowest attitude is consistent with the surface wind patterns.

Qingyuan sounding station was in the stratiform region by 1005 LST. The sounding showed that the northwest flow prevailed below $3 \mathrm{~km}$ altitude. Hong Kong sounding station was in the convective region. The sounding indicated that southeast wind and southwest wind adequate water vapour were shown below $3 \mathrm{~km}$ height (Figure 3 ). These wind patterns were in accordance with dual-radar retrieval on the whole.

The VWP (VAD Wind Profile) reveals the horizontal wind vertical profile near the radar station region. Guangzhou radar was in the stratiform region at 1005 LST. The north wind prevails below $0.9 \mathrm{~km}$ altitude, with speed between 4 and $12 \mathrm{~m} / \mathrm{s}$. It changed to west direction anticlockwise from 0.9 to $3.7 \mathrm{~km}$ altitude. The west wind was $22 \mathrm{~m} / \mathrm{s}$ at $5.2 \mathrm{~km}$ altitude. Above it, the southwest prevailed. The wind direction was consistent with dual-radar retrieval.

Figure 10 shows the reflectivity and the storm-relative radial velocity observed by Guangzhou radar at $1005 \mathrm{LST}$. At the elevation of $0.5^{\circ}$ (Figure 10(b)), the rear-to-front inflow prevailed in the large region of dual-radar analysis domain. At the leading edge, the front-to-rear flow was showed. The convergence line was at $1.2 \mathrm{~km}$ altitude (line $\mathrm{AB})$. At the layer of $1.5^{\circ}$ (Figure $10(\mathrm{c})$ ), the convergence line (line $\mathrm{AB}$ ), which was corresponding to the convection line (Figure 10(a)), was at $2.4 \mathrm{~km}$ height. At the elevation of $2.4^{\circ}$ (Figure $10(\mathrm{~d})$ ), the convergence line (line $\mathrm{AB}$ ) was at $3 \mathrm{~km}$ altitude in the dualradar domain. The convergence line was at $3.5 \mathrm{~km}$ altitude at the layer of $3.4^{\circ}$ (Figure 10(e)). At the elevation of $4.3^{\circ}$ (Figure 10(f)), the divergence was at $6.8 \mathrm{~km}$ altitude. The maximum front outflow was $14 \mathrm{~m} / \mathrm{s}$, and the maximum rear outflow was about $-20 \mathrm{~m} / \mathrm{s}$. Compared with the reflectivity at the low layers, part of the front outflow was in the overhang echo. The storm-relative radial velocity was associated with dual-radar analysis.

Updrafts were observed in the convective region (Figure $9(\mathrm{c})$ ), corresponding to the convergence region and intense reflectivity. The leading updrafts were associated with the storm-relative horizontal southeasterly inflow and spread to the middle and upper altitudes along the squall front. Many intense updraft cores were located along the leading edge. The maximum convective updraft was about $7 \mathrm{~m} / \mathrm{s}$ (Figure $9(\mathrm{~d})$ ). On the other hand, the downdraft zones were located in the stratiform region. The downdrafts were weaker than the updrafts at the same altitude. The updraft and downdraft were weaker than those of a tropical squall line [3].

The reflectivity at $5 \mathrm{~km}$ (Figure 9(b)) was weaker than that at the lower altitudes. The intense reflectivity band over $45 \mathrm{dBZ}$ was narrower than that at the lower altitudes, too. However, the maximum reflectivity was still over $50 \mathrm{dBZ}$. The storm-relative front-to-rear horizontal wind prevailed in both convective cloud and tailing stratiform region. The wind speed was larger than that at the lower altitudes. The maximum speed was about $29 \mathrm{~m} / \mathrm{s}$ in the southwest part of the domain $(x<30 \mathrm{~km})$. Some strong convergence centers less than $-20 \times 10^{-4} \mathrm{~s}^{-1}$ were observed in the convective region (Figure 9(f)).

Figures 11 and 12 present the reflectivity and stormrelative wind field at 1023 and 1041 LST, respectively. The leading edge preserved its shape below $4 \mathrm{~km}$ altitude. Although the echo band of over $30 \mathrm{dBZ}$ split into two parts at $5 \mathrm{~km}$ altitude at 1023 LST (Figure 11(b)), the reflectivity structure (Figures 11(a), 11(b), 12(a), and 12(b)) was similar to that at 1005 LST in general. The storm-relative horizontal wind field (Figures 11(a), 11(b), 12(a), and 12(b)), the vertical velocity (Figures 11 and 12(c)), and the divergence field (Figures 11(d) and $12(d))$ were similar to those at 1005 LST.

\subsubsection{Wind Field Structure along Vertical Cross-Section}

(1) Radar Reflectivity Structure. Figure 13(a) shows the reflectivity and storm-relative horizontal flow contours in the vertical cross-section perpendicular to the squall line. The vertical distribution of the radar echo had two contrastive structures, that is, the convective cloud in the front of the system and the stratiform cloud in the rear. The overhanging radar echo was observed above $7.5 \mathrm{~km}$ ahead of the leading edge. This pattern is also observed in the subtropical [60] and midlatitude [9] squall line but is not in some tropical squall lines $[1,3]$. The storm-relative front-to-rear wind pattern, which was different from those in the literatures, formed the overhanging radar echo as discussed later in Section 3.3.2(4). The reflectivity in the convective region was intense. The maximum reflectivity was over $50 \mathrm{dBZ}$, but it was still weaker than that of a tropical squall line [3]. In the latter, the air is moister and more unstable at the low and middle levels. The water vapour mixing ratio profiles in the two cases were different. In the latter, it is more than $8 \mathrm{~g} / \mathrm{kg}$ at $3 \mathrm{~km}$ altitude and $5 \mathrm{k} / \mathrm{kg}$ at $5 \mathrm{~km}$ altitude. The ETL is $13 \mathrm{~km}$ altitude, which is $1 \mathrm{~km}$ higher than that of our case as shown in Section 3.1.2. As a result, the reflectivity of over $50 \mathrm{dBZ}$ can extend from the surface to the altitude of $5 \mathrm{~km}$ in the latter.

Three convective cells over $40 \mathrm{dBZ}$ lined up along the squall line from left to right. Two cells on the right were higher than the left one. The first cell $(x=80 \mathrm{~km})$ was approximately $6.5 \mathrm{~km}$ in height, and the reflectivity of over $50 \mathrm{dBZ}$ was located at the altitude of $2 \mathrm{~km}$. These cells were vertical in general, and only the cell near the stratiform region was backward slightly. The vertical structure is dependent on 


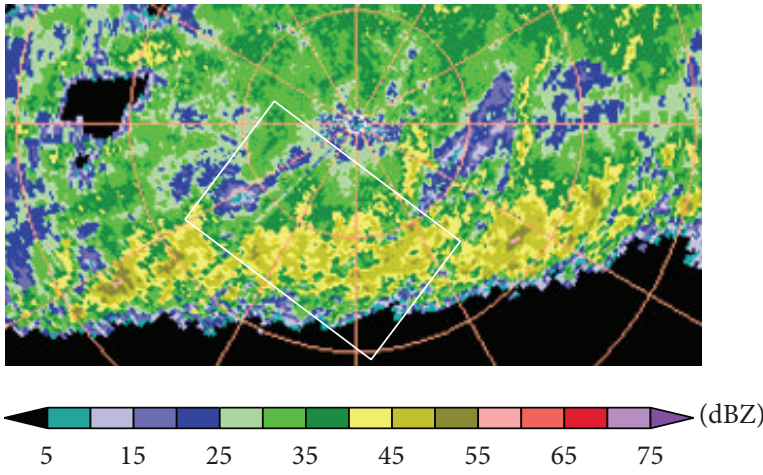

(a)
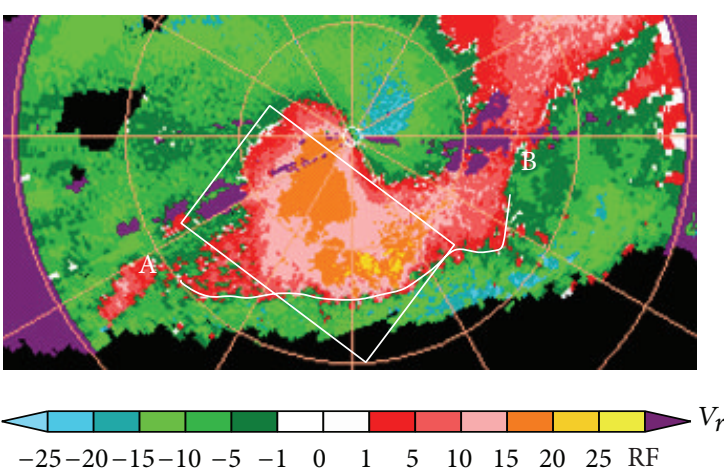

(c)
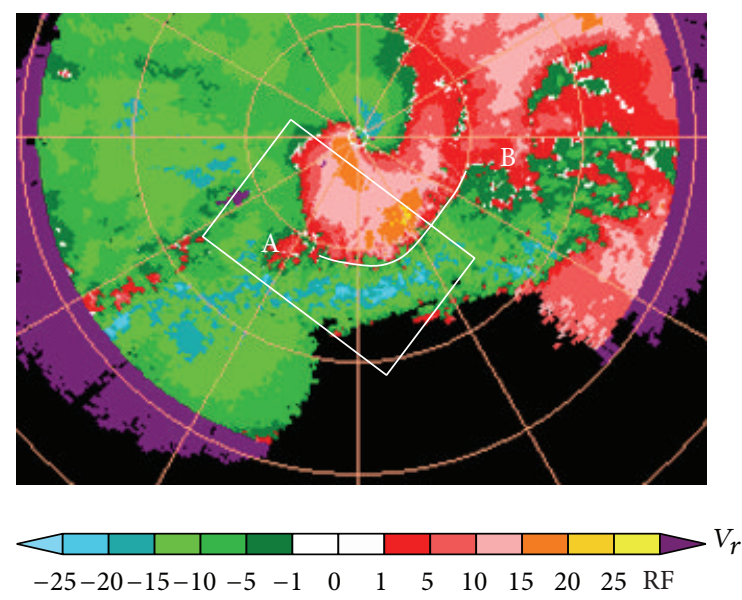

(e)
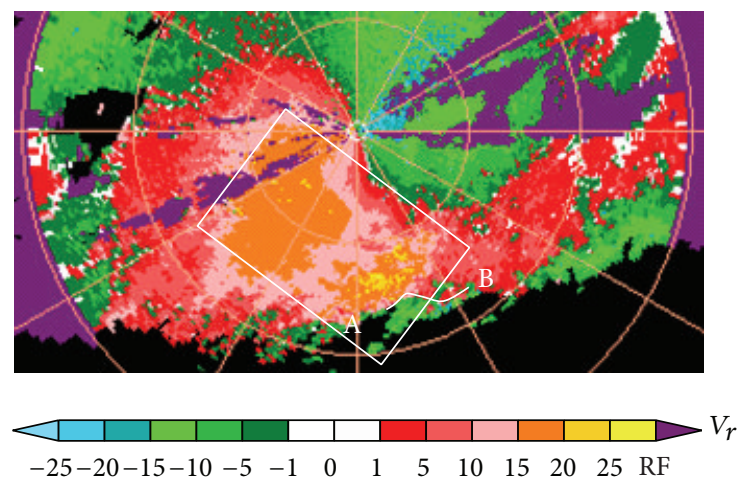

(b)
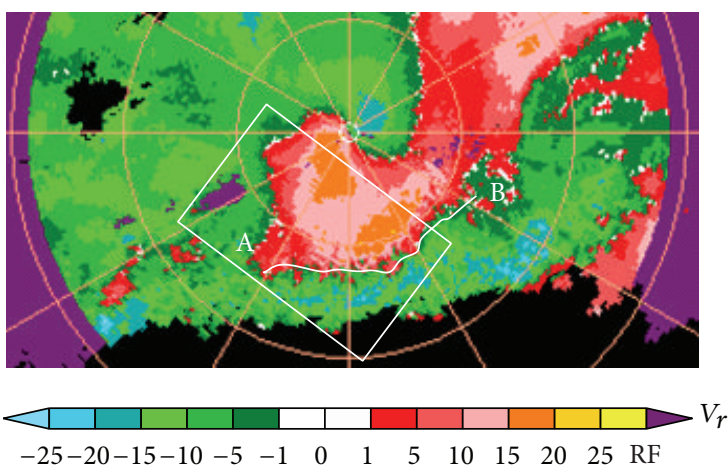

(d)
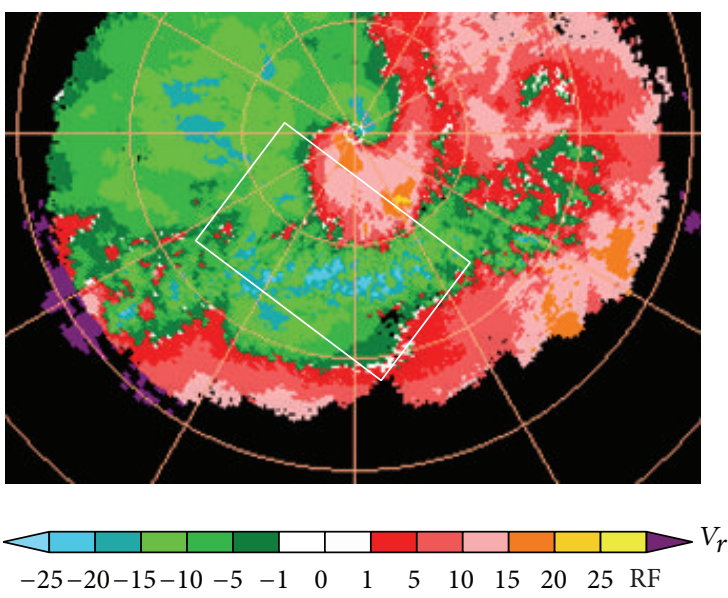

(f)

FIGURE 10: Reflectivity at elevation of $1.5^{\circ}$ (a), storm-relative radial velocity observed by Guangzhou Doppler weather radar at elevation of $0.5^{\circ}$ (b), $1.5^{\circ}$ (c), $2.4^{\circ}$ (d), $3.4^{\circ}$ (e), and $4.3^{\circ}$ (f) on 1005 LST 24 April 2017. Every ring presents $50 \mathrm{~km}$. The rectangles denote the dual-radar analysis domain. The white thick dashed lines indicate the convergence lines.

the development stage [61] and the environment kinematic condition. The upright structure was similar to that of midlatitude $[9,18]$ and other subtropical $[60]$ squall lines. The CAPE, which is a measure of the amount of buoyant energy available in the environment to drive updrafts, is $2300 \mathrm{~J} / \mathrm{kg}$ [62] in a midlatitude squall line [9]. Its environmental instability is more intense than that of our case. This updraft derived by the environmental instability transports moister air to higher region. As a result, the reflectivity with $30 \mathrm{dBZ}$ is dominant compared to $13.4 \mathrm{~km}$ altitude in the midlatitude case [9]. In our case, it was approximately $9.5 \mathrm{~km}$ in height, which was relatively shallow. On the contrary, the convective cell in our case was stronger than that of the TAMEX subtropical squall line [43] but weaker than that of Taiwan other squall lines reported by Chang et al. [60]. The environment instability and moisture contribute to the reflectivity structure.

(2) Storm-Relative Horizontal Airflow Structure. As shown in Figure 13(a), the storm-relative front-to-rear horizontal 


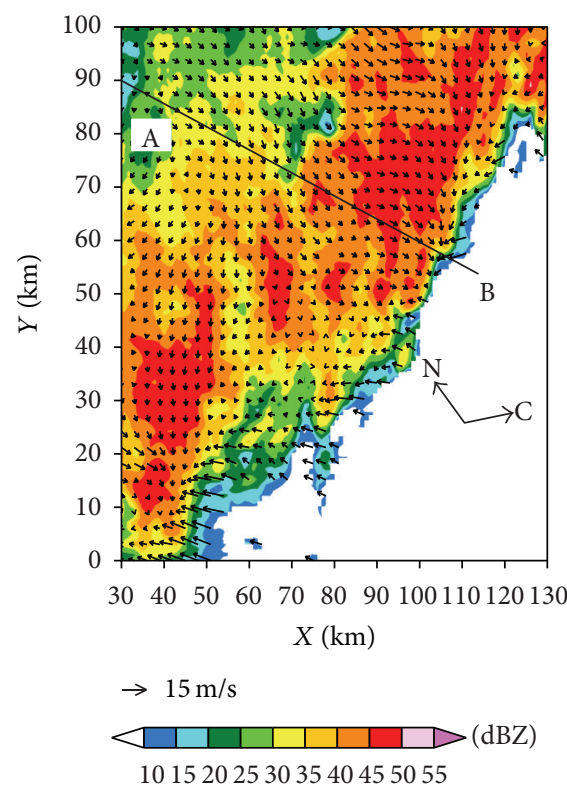

(a)

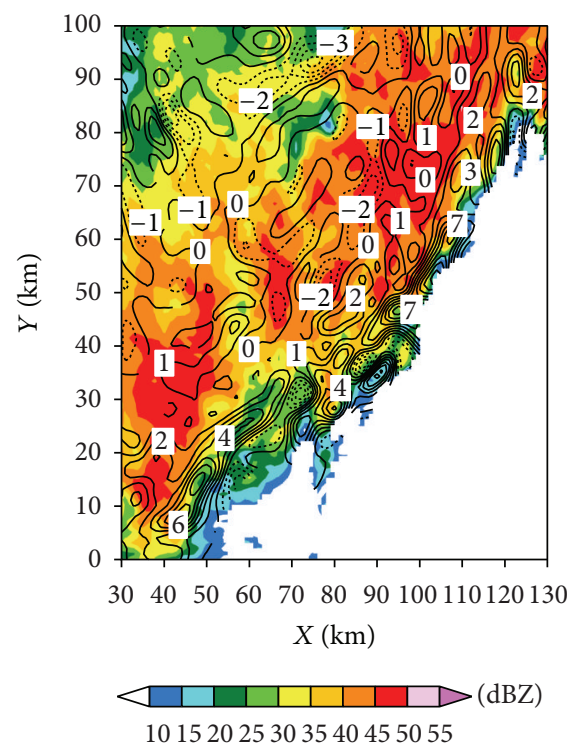

(c)

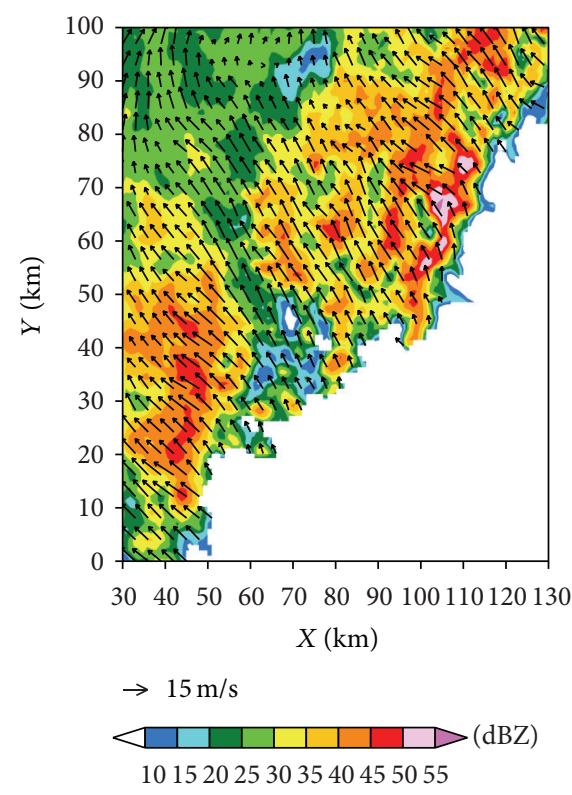

(b)

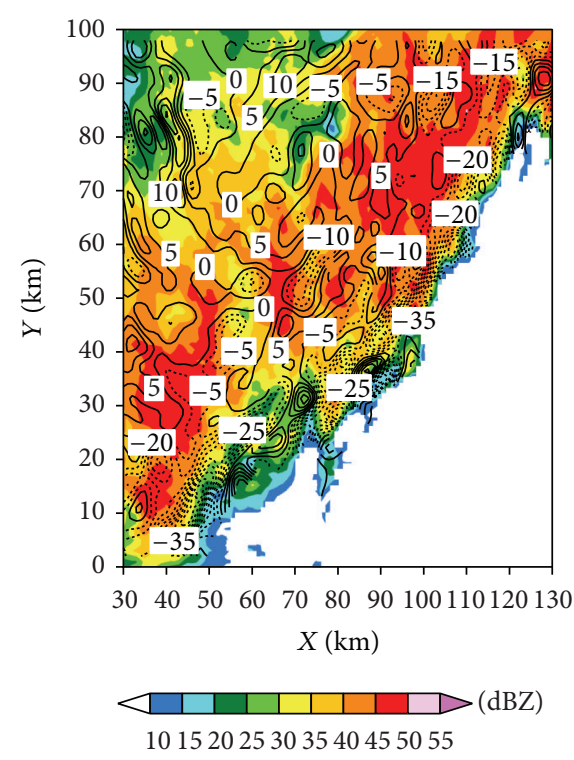

(d)

Figure 11: (a-b) The storm-relative horizontal wind fields at 1.75 and $5 \mathrm{~km}$, respectively, at 1023 LST 24 April 2007. (c) The vertical velocity at $1.75 \mathrm{~km}$. The solid lines are the updraft, and the dashed lines are the downdraft. (d) The divergence field $\left(10^{-4} \mathrm{~s}^{-1}\right)$ at $1.75 \mathrm{~km}$. Solid contours are for positive values (divergence) and dashed contours for negative value (convergence); the contour interval is $5 \times 10^{-4} \mathrm{~s}^{-1}$. The colour shading is radar reflectivity (dBZ).

flow entered the system from the surface to the altitude of $7.5 \mathrm{~km}$ at the leading edge, which was associated with intense upward motion. The intense upward motion was defined as the value over $5 \mathrm{~m} / \mathrm{s}$ and the intense downward motion as the value under $-2 \mathrm{~m} / \mathrm{s}$. Above $7.5 \mathrm{~km}$ of the squall front, part of the flow slopped forward and outward and the other part of the flow rearward. The front-to-rear flow prevailed in the stratiform region and the rear part of the convective region above $3 \mathrm{~km}$. The intense flow was observed at the middle altitudes $(3.5-8 \mathrm{~km})$ mainly, with the speed of more than
$10 \mathrm{~m} / \mathrm{s}$. This rearward flow speed attained the maximum value of more than $20 \mathrm{~m} / \mathrm{s}$ at the altitude of $3.5 \mathrm{~km}(x=73 \mathrm{~km})$, while the rearward flow approaches the maximum of $27 \mathrm{~m} / \mathrm{s}$ in a midlatitude squall line [9]. This inflow was important for the horizontal transports of momentum and moisture into the stratiform region.

The rear-to-font horizontal dry cold inflow entered the stratiform region below $3 \mathrm{~km}$ height and descended from the stratiform region to the convective region. It reduced the hydrometeor mass by evaporation and sublimation [5]. 


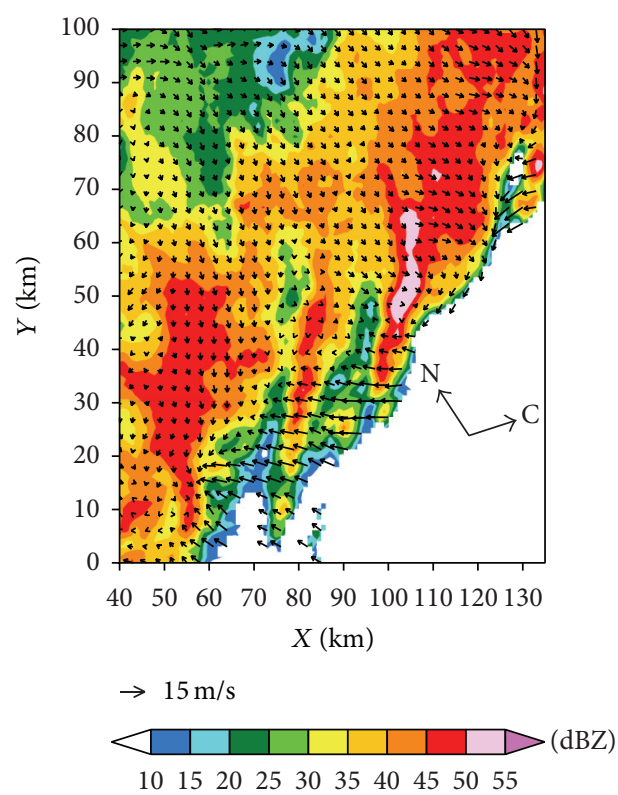

(a)

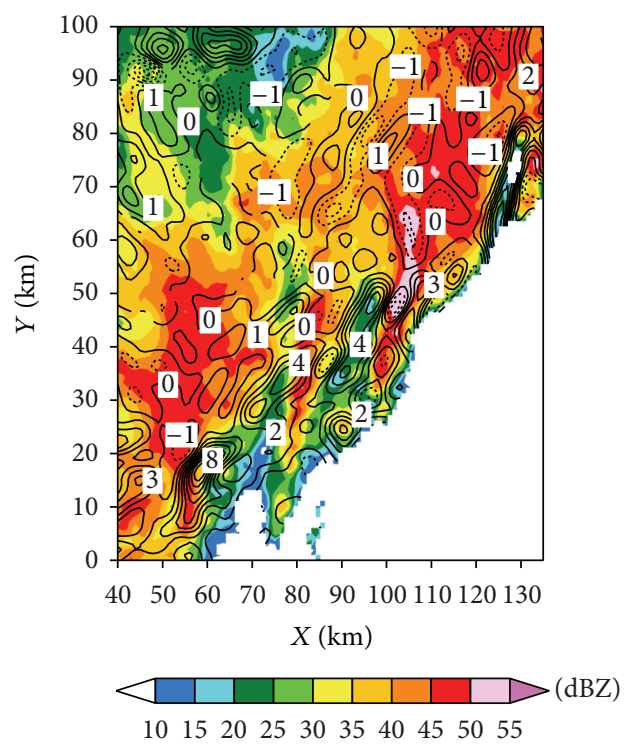

(c)

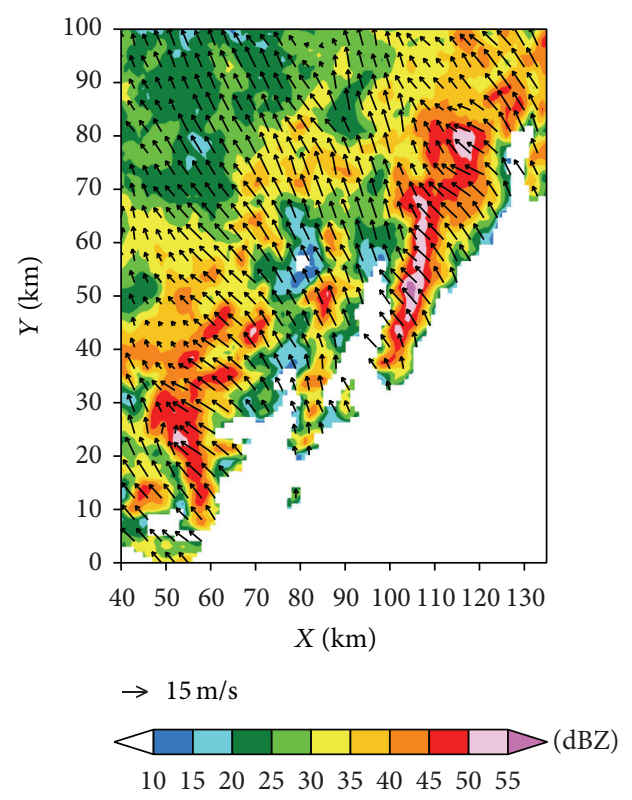

(b)
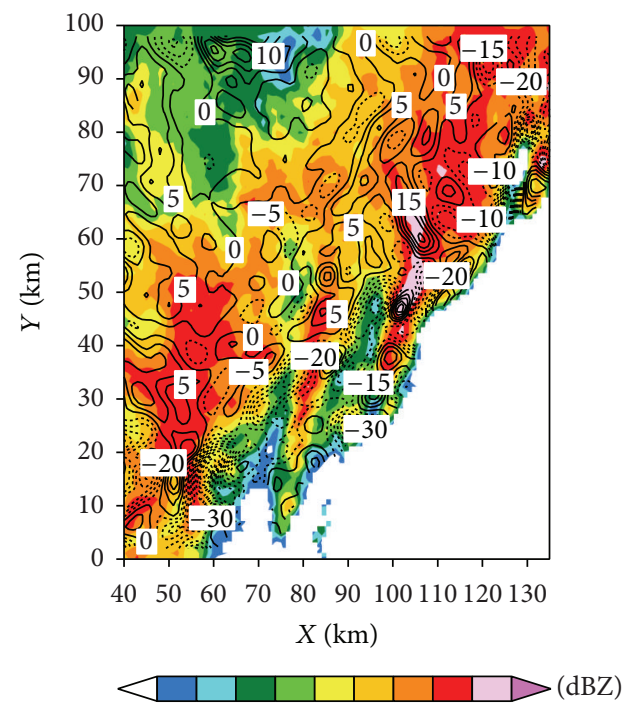

$1015202530 \quad 3540 \quad 455055$

(d)

Figure 12: The same as Figure 11, except at 1041 LST 24 April 2007.

This inflow played an important role in feeding the cold air. Moreover, it reached the maximum speed of approximately $10 \mathrm{~m} / \mathrm{s}$ at the lower altitudes of the second convective cell and finally reached the rear of the third convective cell at the lower altitudes $(x=80 \mathrm{~km})$. As the descending air approaching the surface, it collided with the front-to-rear low-level environmental inflow and formed a gust front. The interaction between the front-to-rear environmental low-level inflow and the rear-to-front environmental midtropospheric flow was responsible for maintaining the updraft-downdraft in the convective region [43]. The depth of the rear-to-front inflow depends on the environmental vertical wind shear. Although the depth in our case was similar to that of the subtropical squall line in the TAMEX [43], the inflow speed was stronger in our case. It was shallower than that of the tropical [1] and midlatitude [9] squall lines. In the midlatitude squall line with higher shear, the inflow can also reach the height of $7.5 \mathrm{~km}$, and the wind speed is stronger than that of our case.

(3) Vertical Velocity Structure. As shown in Figure 13(b), the intense updrafts prevailed at the squall front $(x=72-$ $85 \mathrm{~km}$ ) and extended to the altitude of $9 \mathrm{~km}$. The maximum speed was approximately $13 \mathrm{~m} / \mathrm{s}$ at $6 \mathrm{~km}$ height of the leading edge $(x=82 \mathrm{~km})$. The updraft core was nearly vertical. The intense convective updrafts produced by the boundarylayer convergence contribute to the growth of the convective 


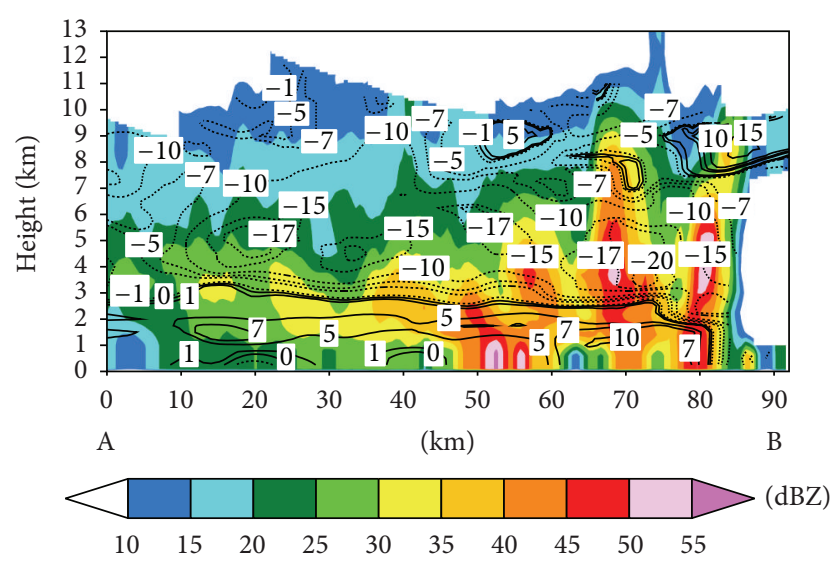

(a)

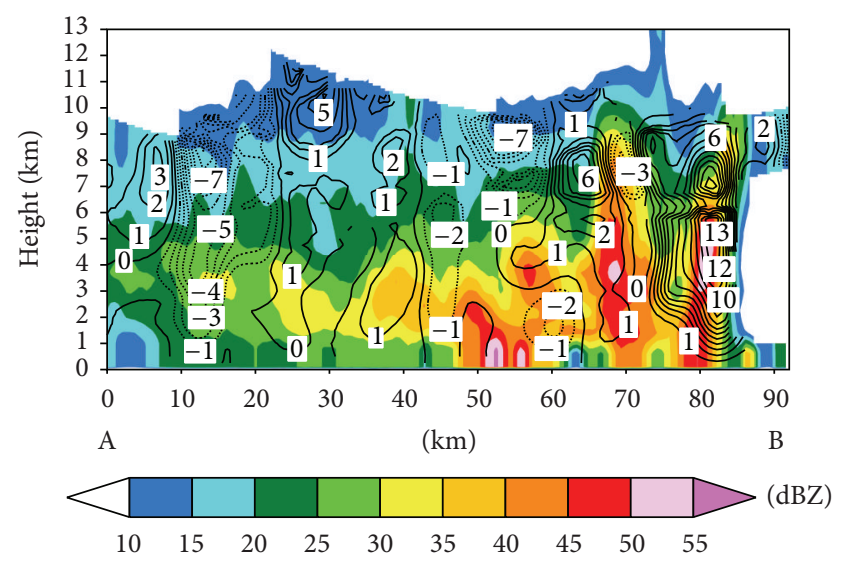

(b)

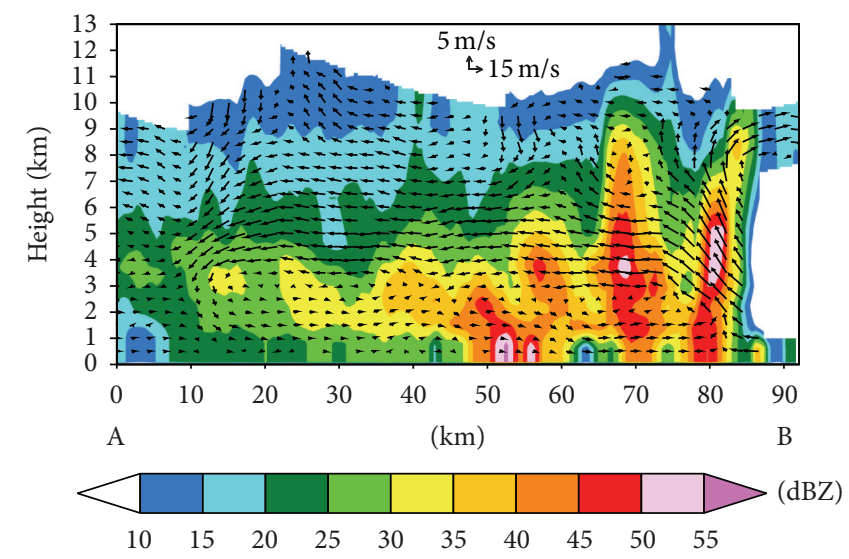

(c)

FIGURE 13: Reflectivity, the storm-relative horizontal air flow (a), the vertical velocity (b), and the storm-relative wind field (c) in the vertical cross-section perpendicular to the squall line (along AB in Figure 11(a)).

cells and the formation of the heavy precipitation. The interaction between the convective updraft and downdraft played an important role in maintaining the $3 \mathrm{D}$ circulation within the squall line [43]. As shown in the sounding, the LLJ in our case was more intense than that of other subtropical squall line [43]. The CAPE is $1369 \mathrm{~J} / \mathrm{kg}$ [43] which is smaller than that of our case. The environmental instability $(\partial \theta / \partial p)$ in our case from surface to midlevel $(600 \mathrm{hPa})$ was $5 \mathrm{~K} /(100 \mathrm{hPa})$, which was more unstable than that of the other subtropical squall line [60]. As higher vertical wind shear and higher environmental instability, the updraft was stronger than those of other subtropical squall lines [43, 60]. In the midlatitude squall line [9], the CAPE and the environmental instability shown in Section 3.3.2(1) are more intense than that of our case. Furthermore, the lifting in the vicinity of surface front helps to initiate the squall line. As a result, the updraft in the convective region is $13.4 \mathrm{~km}$ altitude, which is stronger and deeper than that of our case. The cores of the updrafts decreased in intensity, which was similar to the result reported in [9]. The layer of front-to-rear inflow in the convective cell was dominated by upward motion, which is also found in the midlatitude [9] and other subtropical
$[43,60]$ squall lines. There was a shallow and weak downdraft with the speed of $2 \mathrm{~m} / \mathrm{s}$ at the lower altitudes behind the second convective cell in our case. The updraft and downdraft were observed alternately in the stratiform region.

(4) Storm-Relative Wind Field Structure. As shown in Figure 13(c), the storm-relative front-to-rear deep ascending wind began at the lower altitudes of the leading edge and extended upward through the convective region where the strong updraft over $10 \mathrm{~m} / \mathrm{s}$ was located (Figure 13(b)). The updraft was forced by the cold rear inflow at the low levels. The front-to-rear flow transported the unstable and moist presquall line air into the convective cells. The updraft further transferred the water vapour into the upper levels of the troposphere. Convergence was prominent at the low and middle levels of the convective region. Flow above $7.5 \mathrm{~km}$ was divergent in the zone of convective updraft. As the result of divergence from the convective updrafts, part of the flow carrying the particles sloped gradually into upstream and formed trailing stratiform precipitation [60]. Other part of this flow diverted forward toward the leading. It transported the particles downstream and played an important role in 
forming and maintaining the overhanging radar echo at the middle and upper altitudes of the leading edge. The overhanging wind structure depended on the vertical wind structure of the environment relative to the orientation of the squall line. This flow distribution was different from that of the tropical $[1,3]$ and other subtropical [46] squall lines. In the previous studies, the storm-relative front-to-rear wind directs into the squall lines from the front at all levels $[1,3,46]$, with a relative minimum appearing at $700-600 \mathrm{mb}$ generally [3].

The storm-relative rear-to-front cold flow prevailed below the altitude of $3 \mathrm{~km}$ only in the trailing stratiform region. It entered the back edge of the convective cloud at the lower altitudes. The midtropospheric air was cooler than the surrounding air. Its buoyancy was further reduced due to the precipitation loading in the high reflectivity region behind the leading edge. The rear-to-front flow reached the convective line and enhanced the convergence at the lower altitudes. An enclosed circulation was observed at the lower and middle altitudes of the squall line. The interaction between the frontto-rear warm flow and the rear-to-front cold flow at the lower altitudes is conducive to maintain the updraft-downdraft structure in the convective region.

\section{Discussions}

As depicted above, many structural characteristics of this squall line were similar to those of the other subtropical squall line [43]. The squall line was composed of a well-organized convective cloud region, a weak reflectivity transition region under $30 \mathrm{dBZ}$, and a broad stratiform region. The stormrelative front-to-rear wind entered the squall line at the lower and middle altitudes of the leading edge, and the stormrelative rear-to-front wind entered the system at the lower altitudes of the stratiform region.

Our results, however, had presented some important kinematic characteristics different from the reported squall lines. The echo top height is defined as the altitude of $20 \mathrm{dBZ}$ $[3,18]$. First, the echo top in our case was approximately $10 \mathrm{~km}$, and it is $8 \mathrm{~km}$ height in some squall lines in the Taiwan Strait $[43,46]$. In the other squall line of the Taiwan Strait [60], the echo top is more than $13 \mathrm{~km}$. In our case, the overhanging radar echo was observed above $7.5 \mathrm{~km}$ at the leading edge. This echo feature is not seen in the other subtropical squall line [43]. The vertical wind shear in the environment contributes to the echo structure.

Second, the storm-relative front-to-rear horizontal inflow entered the squall line from the surface to the altitude of $7.5 \mathrm{~km}$ at the leading edge and then converted to two outward flows. One was forward and the other rearward. In the other subtropical squall lines $[43,46]$, the front-to-rear wind prevailed at all altitudes.

Third, the rear-to-font cold inflow entered the squall line from the stratiform region below $3 \mathrm{~km}$ only. On the other hand, the inflow prevails at all altitudes in the stratiform region in the other subtropical squall line [60]. The speed was stronger in our case, although the wind pattern was similar to that of a subtropical line in the same latitude zone [43]. The vertical wind structure of the environment contributes to the flow pattern.

Moreover, as shown in Figure 13(b), the intense updrafts prevailed in the squall front and extended to $10 \mathrm{~km}$ in height. The updraft and downdraft were stronger than those of the other subtropical squall line [43].

\section{Conclusions}

The goal of this study is to reveal the evolution features of a subtropical squall line in South China and the 3D wind structural characteristics in its mature period. The retrieval results demonstrated the possibility to perform the dualDoppler retrieval analysis from operational radars, too. We have presented some new structures as demonstrated in Section 4.

A conceptual model of this squall line in the vertical cross-section perpendicular to the squall line is summarized in Figure 14. The squall line included a convective region, a weak reflectivity transition region under $30 \mathrm{dBZ}$, and a trailing stratiform region. The convective region was intense. The storm-relative front-to-rear warm flow entered the squall line from the surface to the altitude of $7.5 \mathrm{~km}$ at the leading edge, which was associated with intense upward motions. Above $7.5 \mathrm{~km}$ height, part of the inflow sloped gradually into the trailing stratiform cloud; part of the front-to-rear inflow sloped into the leading convective cloud and then moved forward. Below the altitude of $3 \mathrm{~km}$ in the wide trailing stratiform region, the descending shallow rear-to-front cold inflow entered the squall line, playing an important role in feeding the cold air. The rear-to-front inflow blew forward, and finally part of the cold inflow converged with the frontto-rear deep warm inflow at the convective line. It resulted in intense updraft and strong convergence at the lower altitudes. New cells formed at the squall front, due to the front-to-rear inflow at the lower altitudes of the gust front. It should be of interest and importance to know how the dynamics within the squall line connected with microphysics. This topic will be explored by numerical simulation in future. The squall line studied in the present was only a particular case. In order to summarize the general features of the squall line over South China, more cases should be studied.

\section{Competing Interests}

The author declares that there is no conflict of interests regarding the publication of this paper.

\section{Acknowledgments}

This research was supported by the National Natural Science Foundation of China (Grant no. 41275041), the China National High Technology Research and Development Program "863" Project (Grant no. 2007AA061901), and the National Special Scientific Fund in the Public Service (Grant no. GYHY201406003). The author wishes to thank Dr. Mario Marcello Miglietta at Institute of Atmospheric Sciences and 


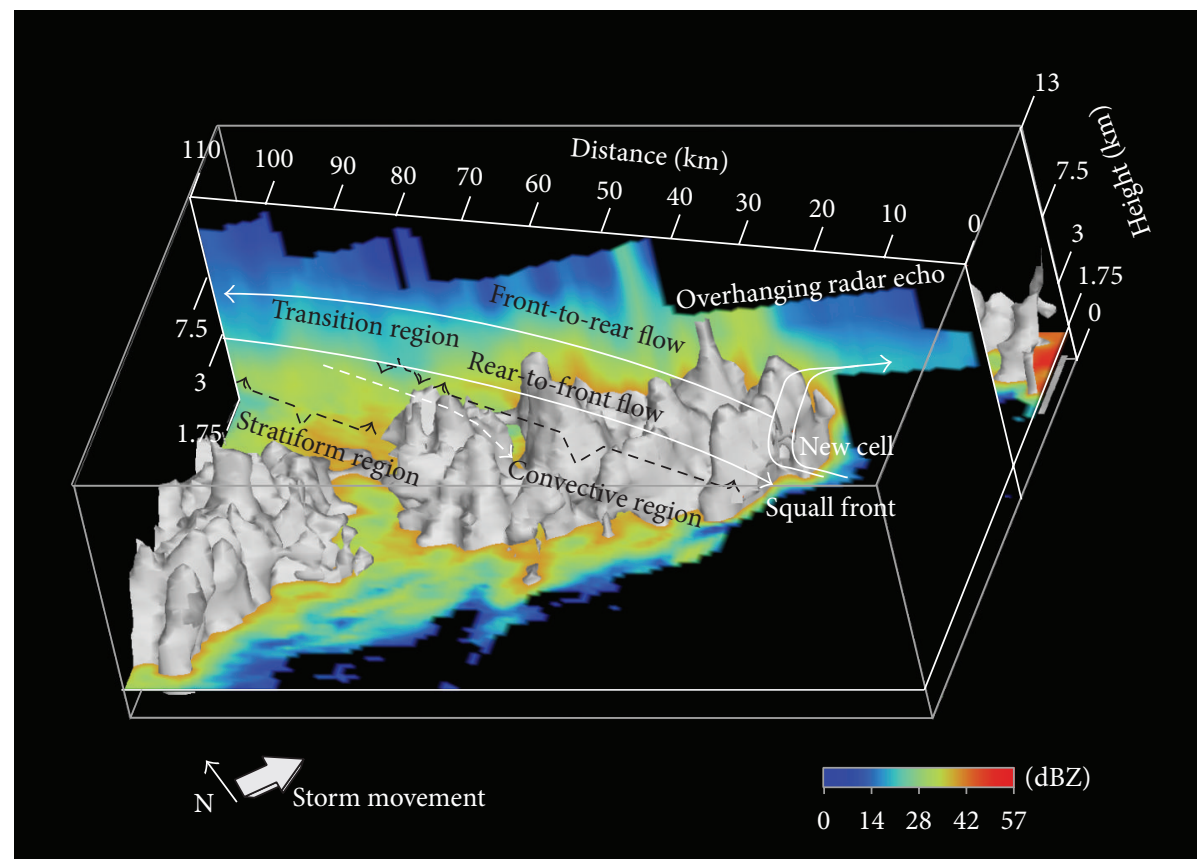

FIGURE 14: A 3D conceptual model of the squall line. White isosurfaces present the radar reflectivity of over $40 \mathrm{dBZ}$. The horizontal colour shading presents the radar reflectivity at $1.75 \mathrm{~km}$. The vertical colour shading is the reflectivity in the vertical cross-section perpendicular to the squall line. The white thin solid arrows in the vertical cross-section are the storm-relative wind field. The arrow indicates the north (N). The $3 \mathrm{D}$ gray arrow presents the storm movement direction.

Climate (CNR-ISAC) for his insightful comments and constructive suggestions to improving this manuscript.

\section{References}

[1] E. J. Zipser, "Mesoscale and convective-scale downdrafts as distinct components of squall-line structure," Monthly Weather Review, vol. 105, no. 12, pp. 1568-1589, 1977.

[2] F. Roux, J. Testud, M. Payen, and B. Pinty, "West African squallline thermodynamic structure retrieved from dual-Doppler radar observations," Journal of the Atmospheric Sciences, vol. 41, no. 21, pp. 3104-3121, 1984.

[3] M. Chong, P. Amayenc, G. Scialom, and J. Testud, "A tropical squall line observed during the COPT 81 experiment in West Africa. Part I: kinematic structure inferred from dual-Doppler radar data," Monthly Weather Review, vol. 115, no. 3, pp. 670694, 1987.

[4] C. J. Kessinger, P. S. Ray, and C. E. Hane, "The Oklahoma squall line of 19 May 1977. Part I: a multiple Doppler analysis of convective and stratiform structure," Journal of the Atmospheric Sciences, vol. 44, no. 19, pp. 2840-2865, 1987.

[5] M. I. Biggerstaff and R. A. Houze Jr., "Kinematic and precipitation structure of the 10-11 June 1985 squall line," Monthly Weather Review, vol. 119, no. 12, pp. 3034-3065, 1991.

[6] M. R. Clark, "Doppler radar observations of mesovortices within a cool-season tornadic squall line over the UK," Atmospheric Research, vol. 100, no. 4, pp. 749-764, 2011.

[7] C. A. Leary and R. A. Houze Jr., "The structure and evolution of convection in a tropical cloud cluster," Journal of the Atmospheric Sciences, vol. 36, no. 3, pp. 437-457, 1979.
[8] H. Morrison, S. A. Tessendorf, K. Ikeda, and G. Thompson, "Sensitivity of a simulated midlatitude squall line to parameterization of raindrop breakup," Monthly Weather Review, vol. 140, no. 8, pp. 2437-2460, 2012.

[9] R. A. Houze Jr., S. A. Rutledge, M. I. Biggerstaff, and B. F. Smull, "Interpretation of Doppler weather radar displays of midlatitude mesoscale convective systems," Bulletin of the American Meteorological Society, vol. 70, no. 6, pp. 608-619, 1989.

[10] D. P. Jorgensen, M. A. Lemone, and S. B. Trier, "Structure and evolution of the 22 February 1993 TOGA COARE squall line: aircraft observations of precipitation, circulation, and surface energy fluxes," Journal of the Atmospheric Sciences, vol. 54, no. 15, pp. 1961-1985, 1997.

[11] R. A. Houze, "Structure and dynamics of a tropical squall-line system," Monthly Weather Review, vol. 105, no. 12, pp. 1540-1567, 1977.

[12] S. A. Braun and R. A. Houze Jr., "The heat budget of a midlatitude squall line and implications for potential vorticity production," Journal of the Atmospheric Sciences, vol. 53, no. 9, pp. 1217-1240, 1996.

[13] M. Chong and O. Bousquet, "A mesovortex within a nearequatorial mesoscale convective system during TOGA COARE," Monthly Weather Review, vol. 127, no. 6, pp. 11451156, 1999.

[14] W. A. Petersen, R. C. Cifelli, S. A. Rutledge, B. S. Ferrier, and B. F. Smull, "Shipborne dual-doppler operations during TOGA COARE: integrated observations of storm kinematics and electrification," Bulletin of the American Meteorological Society, vol. 80, no. 1, pp. 81-97, 1999.

[15] J.-J. Wang and L. D. Carey, "The development and structure of an oceanic squall-line system during the South China Sea 
monsoon experiment," Monthly Weather Review, vol. 133, no. 6, pp. 1544-1561, 2005.

[16] J. Mateo, D. Ballart, C. Brucet, M. Aran, and J. Bech, "A study of a heavy rainfall event and a tornado outbreak during the passage of a squall line over Catalonia," Atmospheric Research, vol. 93, no. 1-3, pp. 131-146, 2009.

[17] S.-A. Jung, D.-I. Lee, B. J.-D. Jou, and H. Uyeda, "Microphysical properties of maritime squall line observed on June 2, 2008 in Taiwan," Journal of the Meteorological Society of Japan, vol. 90, no. 5, pp. 833-850, 2012.

[18] J.-H. Jeong, D.-I. Lee, C.-C. Wang, S.-M. Jang, S.-H. Park, and S.-A. Jung, "Structure and evolution of line-shaped convective systems associated with Changma front during GRL PHONE09: 6 July 2009 case," Meteorological Applications, vol. 21, no. 3, pp. 786-794, 2014.

[19] E. A. Kalina, K. Friedrich, S. M. Ellis, and D. W. Burgess, "Comparison of disdrometer and X-band mobile radar observations in convective precipitation," Monthly Weather Review, vol. 142, no. 7, pp. 2414-2435, 2014.

[20] M. M. Miglietta and R. Rotunno, "Numerical simulations of sheared conditionally unstable flows over a mountain ridge," Journal of the Atmospheric Sciences, vol. 71, no. 5, pp. 1747-1762, 2014.

[21] A. Manzato, S. Davolio, M. M. Miglietta, A. Pucillo, and M. Setvák, "12 September 2012: a supercell outbreak in NE Italy?" Atmospheric Research, vol. 153, pp. 98-118, 2015.

[22] R. M. Wakimoto, P. Stauffer, and W.-C. Lee, "The vertical vorticity structure within a squall line observed during BAMEX: banded vorticity features and the evolution of a bowing segment," Monthly Weather Review, vol. 143, no. 1, pp. 341-362, 2015.

[23] D. B. Giaiotti and F. Stel, "A multiscale observational case study of an isolated tornadic supercell," Atmospheric Research, vol. 83, no. 2-4, pp. 152-161, 2007.

[24] M. M. Miglietta and A. Regano, "An observational and numerical study of a flash-flood event over south-eastern Italy," Natural Hazards and Earth System Science, vol. 8, no. 6, pp. 1417-1430, 2008.

[25] B. Antonescu, S. Burcea, and A. Tănase, "Forecasting the onset of cloud-to-ground lightning using radar and upper-air data in Romania," International Journal of Climatology, vol. 33, no. 6, pp. 1579-1584, 2013.

[26] B. Antonescu, G. Vaughan, and D. M. Schultz, "A five-year radar-based climatology of tropopause folds and deep convection over Wales, United Kingdom," Monthly Weather Review, vol. 141, no. 5, pp. 1693-1707, 2013.

[27] B. Antonescu and A. Bell, “Tornadoes in Romania," Monthly Weather Review, vol. 143, no. 3, pp. 689-701, 2015.

[28] G. Vaughan, J. Methven, D. Anderson et al., "Cloud banding and winds in intense European cyclones: results from the DIAMET project," Bulletin of the American Meteorological Society, vol. 96, no. 2, pp. 249-265, 2015.

[29] P. W. Chan and K. K. Hon, "Observation and numerical simulation of terrain-induced windshear at the hong kong international airport in a planetary boundary layer without temperature inversions," Advances in Meteorology, vol. 2016, Article ID 1454513, 9 pages, 2016.

[30] N. R. Dalezios and P. T. Nastos, "Milestones of the diachronic evolution of meteorology," International Journal of Global Environmental Issues, vol. 15, no. 1-2, pp. 49-69, 2016.
[31] H. Lee, E. K. Kim, and S. Kim, "Anomalous propagation echo classification of imbalanced radar data with support vector machine," Advances in Meteorology, vol. 2016, Article ID 4129708, 13 pages, 2016.

[32] M. M. Miglietta and R. Rotunno, "An EF3 multivortex tornado over the Ionian region: is it time for a dedicated warning system over Italy?" Bulletin of the American Meteorological Society, vol. 97, no. 3, pp. 337-344, 2016.

[33] C.-H. You, D.-I. Lee, S.-M. Jang et al., "Characteristics of rainfall systems accompanied with Changma front at Chujado in Korea," Asia-Pacific Journal of Atmospheric Sciences, vol. 46, no. 1, pp. 41-51, 2010.

[34] J.-H. Jeong, D.-I. Lee, C.-C. Wang, S.-M. Jang, C.-H. You, and M. Jang, "Environment and morphology of mesoscale convective systems associated with the Changma front during 9-10 July 2007," Annales Geophysicae, vol. 30, no. 8, pp. 1235$1248,2012$.

[35] D.-S. Kim, M. Maki, S. Shimizu, and D.-I. Lee, "X-band dualpolarization radar observations of precipitation core development and structure in a multi-cellular storm over Zoshigaya, Japan, on August 5, 2008," Journal of the Meteorological Society of Japan, vol. 90, no. 5, pp. 701-719, 2012.

[36] S.-M. Jang, D.-I. Lee, J.-H. Jeong et al., "Radar reflectivity and wind fields analysis by using two X-band Doppler radars at Okinawa, Japan from 11 to 12 June 2007," Meteorological Applications, vol. 21, no. 4, pp. 898-909, 2014.

[37] M. Oue, T. Ohigashi, K. Tsuboki, and E. Nakakita, "Vertical distribution of precipitation particles in Baiu frontal stratiform intense rainfall around Okinawa Island, Japan," Journal of Geophysical Research D: Atmospheres, vol. 120, no. 11, pp. 56225637, 2015.

[38] E. Drigeard, E. Fontaine, W. Wobrock et al., "A comparison of airborne in situ cloud microphysical measurement with ground-based C-band radar observations in deep stratiform regions of African squall lines," Journal of Applied Meteorology and Climatology, vol. 54, no. 12, pp. 2461-2477, 2015.

[39] B. F. Smull and R. A. Houze, "Dual-Doppler radar analysis of a midlatitude squall line with a trailing region of stratiform rain," Journal of the Atmospheric Sciences, vol. 44, no. 15, pp. 21282149, 1987.

[40] S. A. Braun and R. A. Houze, "The transition zone and secondary maximum of radar reflectivity behind a midlatitude squall line: results retrieved from Doppler radar data," Journal of the Atmospheric Sciences, vol. 51, no. 19, pp. 2733-2755, 1994.

[41] J. D. Locatelli, M. T. Stoelinga, and P. V. Hobbs, "Structure and evolution of winter cyclones in the Central United States and their effects on the distribution of precipitation. Part V: thermodynamic and dual-Doppler radar analysis of a squall line associated with a cold front aloft," Monthly Weather Review, vol. 126, no. 4, pp. 860-875, 1998.

[42] D. P. Jorgensen, Z. Pu, P. O. G. Persson, and W.-K. Tao, "Variations associated with cores and gaps of a pacific narrow cold frontal rainband," Monthly Weather Review, vol. 131, no. 11, pp. 2705-2729, 2003.

[43] T. C. Wang, Y. Lin, H. Shen, and R. W. Pasken, "Characteristics of a subtropical squall line determined from TAMEX dualdoppler data. Part I: kinematic structure," Journal of the Atmospheric Sciences, vol. 47, no. 20, pp. 2357-2381, 1990.

[44] Y.-J. Lin, H. Shen, and R. W. Pasken, "Kinetic energy budgets of a subtropical squall line determined from TAMEX dual-Doppler measurements," Monthly Weather Review, vol. 119, no. 11, pp. 2654-2663, 1991. 
[45] P. S. Ray, A. Robinson, and Y. Lin, "Radar analysis of a TAMEX frontal system," Monthly Weather Review, vol. 119, no. 11, pp. 2519-2539, 1991.

[46] J.-H. Teng, C.-S. Chen, T.-C. C. Wang, and Y.-L. Chen, "Orographic effects on a squall line system over Taiwan," Monthly Weather Review, vol. 128, no. 4, pp. 1123-1138, 2000.

[47] C.-K. Yu and C.-L. Tsai, "Structural and surface features of arcshaped radar echoes along an outer tropical cyclone rainband," Journal of the Atmospheric Sciences, vol. 70, no. 1, pp. 56-72, 2013.

[48] H. G. Zhou, Y. B. Wang, and P. Y. Zhang, "A software system for retrieving 3D wind fields from dual-Doppler radar and the 3D wind structure of heavy rain," in Proceedings of the International Symposium on Climate Changes (ISCC '03), WMO/TDNO.1172, pp. 290-293, WMO, Beijing, China, 2003.

[49] R. Oye, C. Mueller, and S. Smith, "Software for radar translation, visualization, editing, and interpolation," in Proceedings of the 27th Conference on Radar Meteorology, pp. 359-361, American Meteorological Society, Vail, Colo, USA, October 1995.

[50] J. Zhang and S. Wang, "An automated 2D multipass Doppler radar velocity dealiasing scheme," Journal of Atmospheric and Oceanic Technology, vol. 23, no. 9, pp. 1239-1248, 2006.

[51] H. G. Zhou, "China new generation weather radar three dimensional mosaic software system and application," in Proceedings of the International Conference on Computer Science and Service System (CSSS '11), vol. 1, pp. 271-275, Nanjing, China, June 2011.

[52] J. Zhang, K. Howard, and J. J. Gourley, "Constructing threedimensional multiple-radar reflectivity mosaics: examples of convective storms and stratiform rain echoes," Journal of Atmospheric and Oceanic Technology, vol. 22, no. 1, pp. 30-42, 2005.

[53] O. Bousquet and M. Chong, "A multiple-Doppler synthesis and continuity adjustment technique (MUSCAT) to recover wind components from Doppler radar measurements," Journal of Atmospheric and Oceanic Technology, vol. 15, no. 2, pp. 343-359, 1998.

[54] M. Chong and O. Bousquet, "On the application of MUSCAT to a ground-based dual-Doppler radar system," Meteorology and Atmospheric Physics, vol. 78, no. 1-2, pp. 133-139, 2001.

[55] O. Bousquet and P. Tabary, "Development of a nationwide realtime 3-D wind and reflectivity radar composite in France," Quarterly Journal of the Royal Meteorological Society, vol. 140, no. 679, pp. 611-625, 2014.

[56] H. G. Zhou and P. Y. Zhang, "A new technique of recovering three-dimensional wind fields from simulated dual-Doppler radar in the Cartesian space," Acta Meteorologica Sinica, vol. 60, no. 5, pp. 585-593, 2002.

[57] M. Chong and J. Testud, “Three-dimensional wind field analysis from dual-Doppler radar data. Part III: the boundary condition: an optimum determination based on a variational concept," Journal of Climate and Applied Meteorology, vol. 22, no. 7, pp. 1227-1241, 1983.

[58] H. G. Zhou, "Structure of meso- $\beta$ and $-\gamma$-scale on South China heavy rainfall on 12 13 June 2005 using dual-Doppler radar," Journal of Tropical Meteorology, vol. 13, no. 2, pp. 137-140, 2005.

[59] H. G. Zhou, "Study on the mesoscale structure of the heavy rainfall on Meiyu front with dual-Doppler radar," Atmospheric Research, vol. 93, no. 1-3, pp. 335-357, 2009.

[60] W.-Y. Chang, W.-C. Lee, and Y.-C. Liou, "The kinematic and microphysical characteristics and associated precipitation efficiency of subtropical convection during SoWMEX/TiMREX," Monthly Weather Review, vol. 143, no. 1, pp. 317-340, 2015.
[61] R. Rotunno, J. B. Klemp, and M. L. Weisman, "A theory for strong, long-lived squall lines," Journal of the Atmospheric Sciences, vol. 45, no. 3, pp. 463-485, 1988.

[62] R. H. Johnson and P. J. Hamilton, "The relationship of surface pressure features to the precipitation and airflow structure of an intense midlatitude squall line," Monthly Weather Review, vol. 116, no. 7, pp. 1444-1473, 1988. 

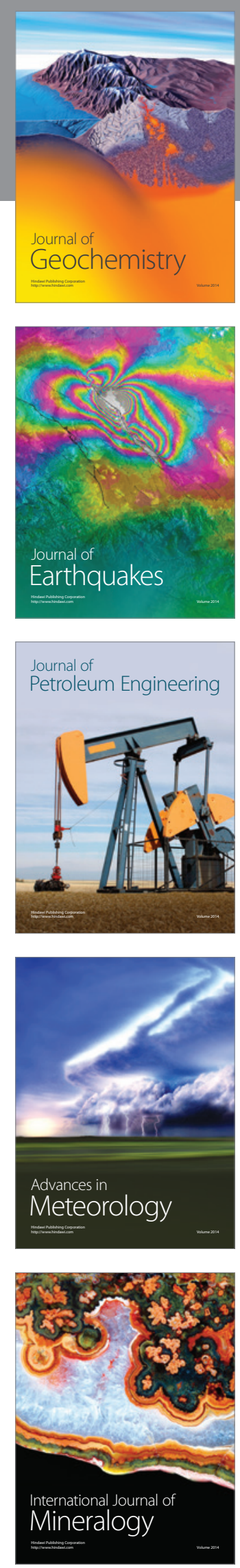
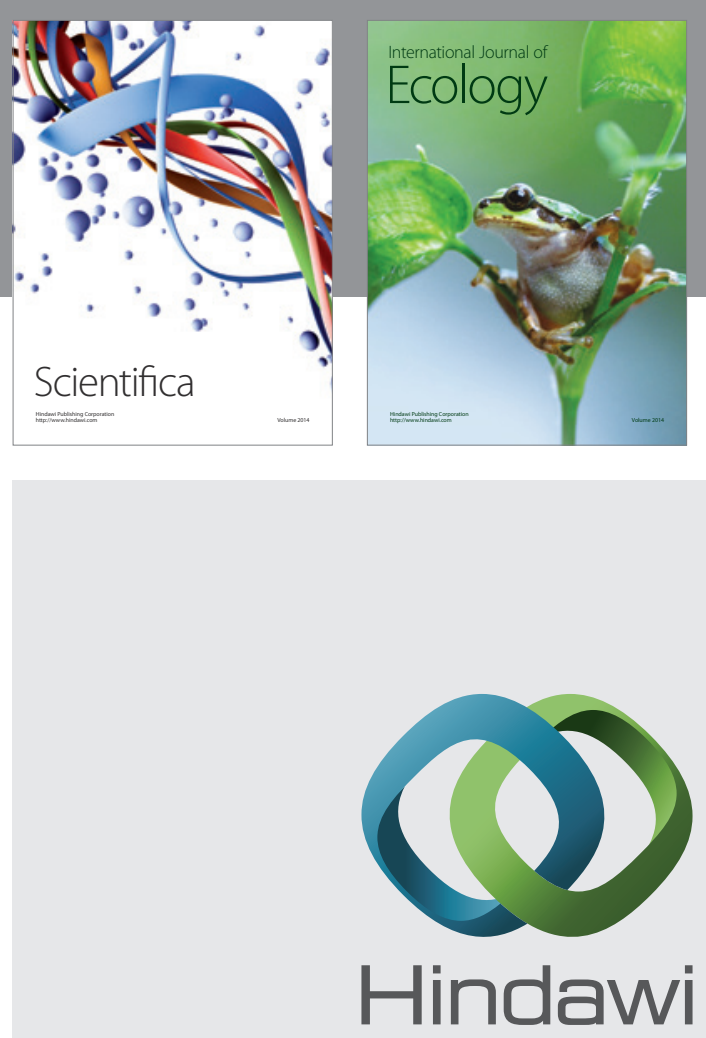

Submit your manuscripts at

http://www.hindawi.com
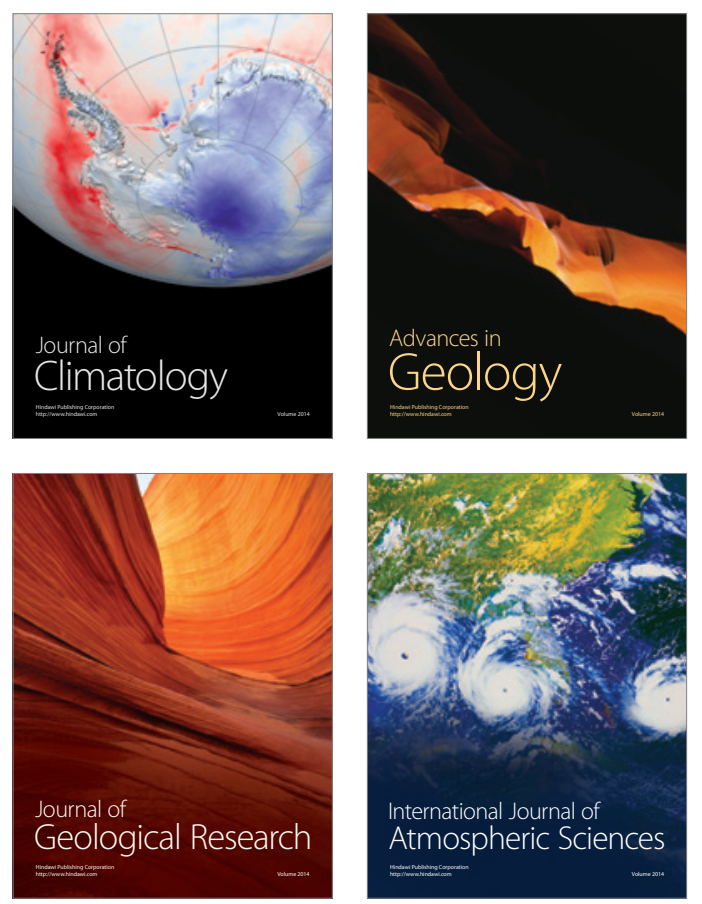

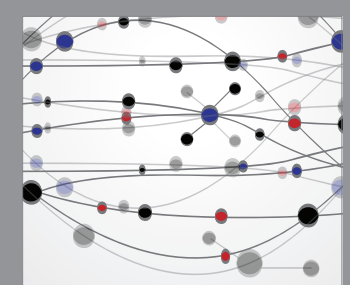

The Scientific

\section{World Journal}
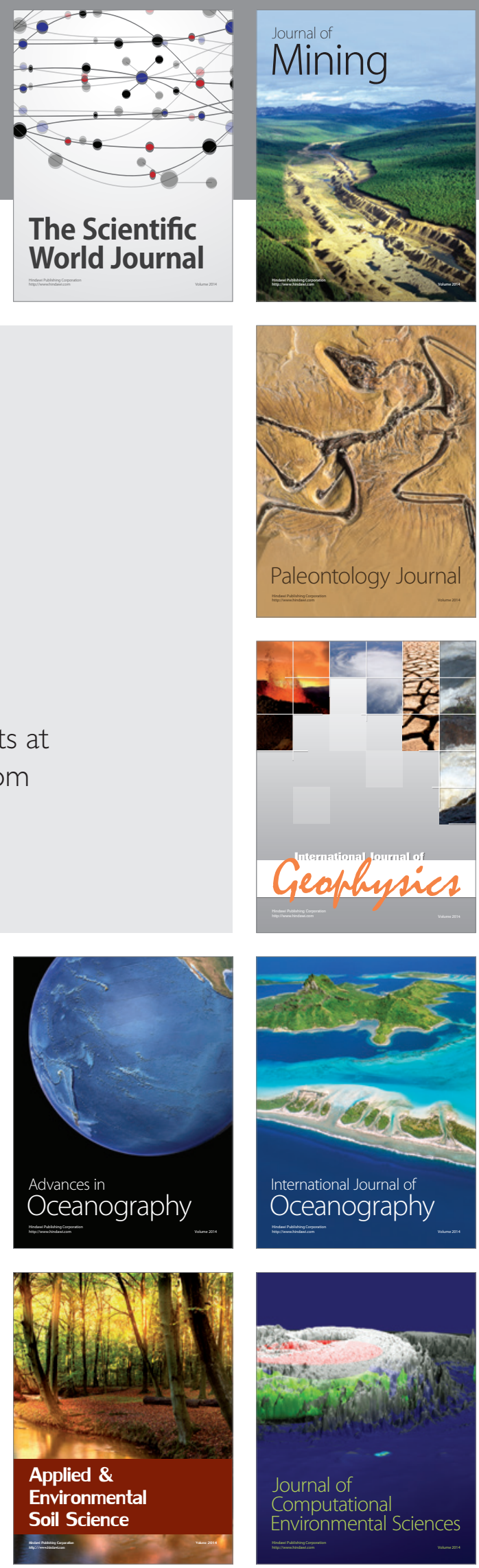